\title{
Mining salinisation of rivers: its impact on diatom (Bacillariophyta) assemblages
}

\author{
Małgorzata BĄK ${ }^{1 *}$, Dariusz HalabowsKI ${ }^{2}$, Adrian $\mathrm{KRYK}^{1}$, Iga LeWIN ${ }^{2}$ \& Agnieszka \\ SowA ${ }^{2}$
}

\author{
${ }^{1}$ Institute of Marine and Environmental Sciences, University of Szczecin, Mickiewicza 16a, 70-383 Szczecin, \\ Poland, *Corresponding author e-mail: malgorzata.bak@usz.edu.pl \\ ${ }^{2}$ Institute of Biology, Biotechnology and Environmental Protection, Faculty of Natural Sciences, University of \\ Silesia in Katowice, Bankowa 9, 40-007 Katowice, Poland
}

\begin{abstract}
The composition of the diatom assemblages was analysed in four rivers of Upper Silesia, Poland in 2017. The diatom assemblages studied were found to reflect anthropogenic salinization caused by mining activities. The assemblages in those rivers characterised by the highest salinity (Bolina and Mleczna) showed a relatively low taxonomic richness. The diatom assemblages were dominated by species typical of brackish or marine waters. The rivers with a minimal or weak anthropogenic impact (Centuria and Mitręga) supported taxonomically richer diatom assemblages typical of mid-altitude siliceous or calcareous streams (respectively), that have a fine particulate substratum. The presence of a new species, Planothidium nanum sp. nov., was revealed. The new species shows a unique set of morphological characters, including small size; its elliptical outline as well as very widely-spaced central striae on the sternum valve (sinus) and widely-spaced central striae on the raphe valve allow to separate it from other similar Planothidium.
\end{abstract}

Key words: diatom, mining activities, new species, river salinisation, Upper Silesia, Poland

\section{INTRODUCTION}

Aquatic organisms are the first environmental component that reacts to any hydromorphological and physico-chemical modifications of riverine water quality. Studies of aquatic organisms are therefore very useful in assessing the human impact and detecting any changes in lotic ecosystems. The use of various organisms that react to long- or short-term changes in aquatic environments gives a precise outlook on the health of these ecosystems (ECTOR \& Rimet 2005; Kelly et al. 2009; Li et al. 2010; SolaK et al. 2012; PoIKANE et al. 2016). Additionally, the EU Water Framework Directive (WFD 2000) recommended that all biological components be used in order to have a full view of the ecological status of flowing waters. The diatoms used to monitor waters are particularly good indicators (e.g. KelLy 2002; BĄK et al. 2004; VILBASTE et al. 2004; BąK \& SZLAuer-LuKaszewsKa 2012). They can be found in every aquatic environment in both clean springs and in heavily polluted environments. They settle on various substrates such as stones, macrophytes or on anthropogenic substrates. In addition, diatoms form a large part of the benthos, often reaching a value of 90-95\% (Ács et al. 2004). However, the strong water pollution that is caused by, for example, salinisation is the main factor that limits the occurrence of fauna and flora (WiLliams 1987). Therefore, in heavily polluted water environments in which it is impossible to examine all of the recommended biological elements, diatoms are very good indicators, especially when there is a lack of invertebrates and ichthyofauna.

The central part of Southern Poland is the most urbanised and at the same time the most polluted region. Upper Silesia, which is located in this part of the country, is a historic area in Poland and the Czech Republic (the upper Odra basin and the initial course of the Vistula) and is also one of the most industrialised and urbanised regions in Europe. Upper Silesia has no natural water reservoirs, and it has only artificial reservoirs (LEWIN et al. 2015). The degradation of many of the rivers in this region is primarily connected with hydromorphological transformations, the inflow of domestic sewage from household sewers and salt water from coal mines. These rivers are characterised by an increased concentration of nutrients and chlorides, water hardness and often a very high conductivity (e.g. HALABOwsKI et al. 2019a, 2019b; SPYRA et al. 2015; LeWIN et al. 2018; SowA et al. 2018). The high level of urbanisation of the Upper Silesian region and the use of salts as de-icing agents for roads also contributes to the degradation of the 
surrounding aquatic environments (including the spread of alien and invasive species; HALABOWSKI et al. 2019b; LEWIN et al. 2015).

The algae of the region were studied in a few surveys and primarily concerned phytoplankton and to a lesser extent microphytobenthos (STARMACH 1939; BUCKA 1960, 1964, 1966; HANAK-SCHMAGER 1974; KWANDRANS 1998, 2002; WILK-WoŹNIAK et al. 2011). It came to our attention that specific research on diatoms (Bacillariophyta) in the Polish part of Upper Silesia had not yet been performed, although quite a number of papers have been published on the diatoms that inhabit the waters from neighbouring areas. Most of the published results concerned the diatoms in springs and streams (e.g. KWANDRANS 2007; WoJTAL 2013) and rivers (fewer in water reservoirs), e.g. WOJTAL \& KWANDRANS 2006; CICHON 2016). According to the EU Water Framework Directive (WFD 2000), the biomonitoring that is carried out in Poland is based on macrophytes, ichthyofauna, benthic macroinvertebrates and phytobenthos, including rivers that are located in the studied area. However, accessible data of the state monitoring lack identified taxa lists and detailed data on species are not usually published.

The aims of the presented research were to compare the biodiversity of the diatom assemblages in rivers that are located in the industrial and urban area of Upper Silesia and adjacent regions that are affected by various degrees of anthropogenic pressure and to determine the most important environmental factors that have a significant impact on their structure. Another aim of the study was to assess the ecological condition of the investigated riverine courses based on microphytobenthos.

\section{MATERIALS AND METHODS}

Study area. The study was carried out in four rivers that are located in southern Poland, all of which are part of the Upper Vistula River. Two of the rivers that were studied (the Mleczna and Bolina Rivers) are affected by the coal mining activity in Upper Silesia (Southern Poland). The two remaining study sites are located outside of area of the mining activity (the Centuria and the Mitręga Rivers; Fig. 1). The anthropogenic effects were primarily observed as changes in the physical and chemical parameters of the water and the morphological transformation

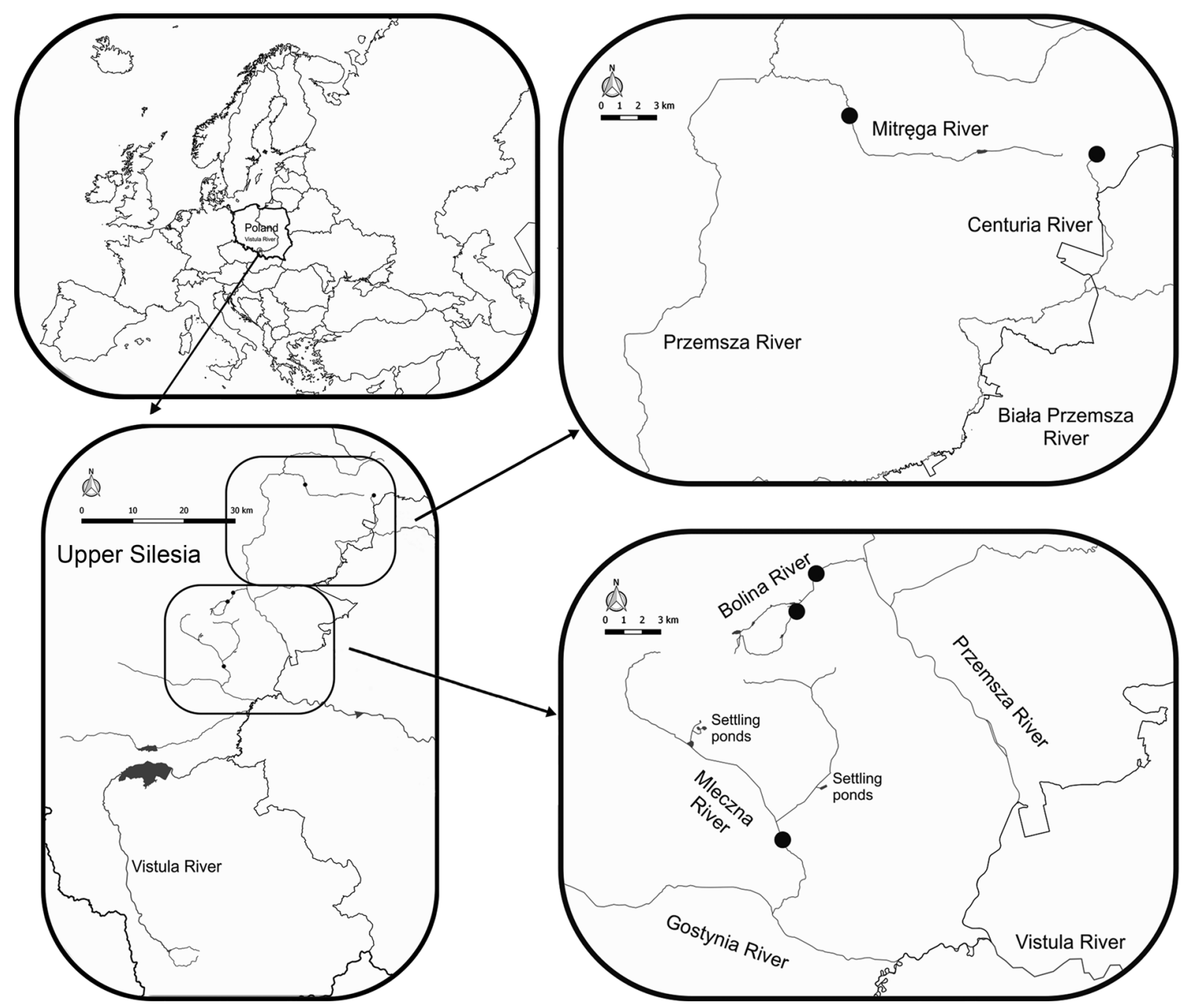

Fig. 1. Location of the study area in Southern Poland and the diatom sampling sites in rivers that were studied. 
of the riverbeds at the research locations. The Mleczna River is characterised by a high mineralisation of the water due to the discharge of underground salt water from four coal mines, i.e. 'KWK Boże Dary', 'KWK Mysłowice-Wesoła', 'KWK Ziemowit' and Experimental Mine 'Barbara'. The water from the 'KWK Boże Dary' coal mine flows through a system of reservoirs before discharging into the river, while the water from the 'KWK Mysłowice-Wesoła' coal mine flows through the Przyrwa River, which is a tributary of the Mleczna River. Two sites (at the upper and lower courses) that have different degrees of water pollution from the coal mines were selected at the Bolina River for the study. The upper course is contaminated by salt water from the 'KWK Murcki-Staszic' coal mine. By contrast, the lower course of the Bolina River is affected by the discharge of underground salt water from the 'KWK Wieczorek' coal mine. The anthropopressure of the study sites on the Mitręga River is caused by a dam reservoir that was constructed a few kilometres away. The sampling site of the Centuria River is not affected by anthropopressure. This site is located near a river spring. The general characteristics of the rivers and the sampling sites are summarised in Tables 1 and 2.

Sampling procedure and taxonomic analyses. The samples were collected four times per sampling site in 2017 (spring, early and late summer, autumn and winter) in order to determine the physical and chemical parameters of the water.
Conductivity, total dissolved solids, $\mathrm{pH}$ and the temperature of the water were measured in the field using a HI 9811-5 pH/ $\mathrm{EC} / \mathrm{TDS} /{ }^{\circ} \mathrm{C}$ meter (Hanna Instruments) and dissolved oxygen was measured using a CO-401 oxygen meter (Elmetron). Salinity was measured using a WTW meter and the result was expressed as the total dissolved solids that had been converted from the measurements of electrical conductivity. For the high anthropogenic impact sites (conductivity $>1000 \mu \mathrm{S} . \mathrm{cm}^{-1}$ ), a conversion factor of $0.72 \times$ conductivity was applied according to PISCART et al. (2005), while for the low anthropogenic impact sites (conductivity $<1000 \mu \mathrm{S} . \mathrm{cm}^{-1}$ ), the conversion factor was $0.77 \times$ conductivity. Analyses of the concentrations of chlorides, sulfates, iron, nutrients, calcium and magnesium as well as total hardness and alkalinity were performed in the laboratory according to the standard methods of HERMANOWICZ et al. (1999). The morphometry of the riverbed, i.e. the average width of the channel, the depth of the river and the flow velocity were also performed in the field.

For the taxonomic analyses, diatoms were taken from a $25 \mathrm{~cm}^{2}$ surface of the bottom sediments or concrete slabs (at each of the study sites). Permanent slides for the light microscopy were prepared following the standard protocol (BATTARBEE 1986; BodÉn 1991). The samples were treated with $10 \%$ hydrochloric acid $(\mathrm{HCl})$ to remove any calcium carbonate and after a thorough washing, they were boiled in $37 \%$ hydrogen peroxide $\left(\mathrm{H}_{2} \mathrm{O}_{2}\right)$ to eliminate any organic

Table 1. General characteristics of the sites that were investigated.

\begin{tabular}{|c|c|c|c|c|c|}
\hline Characteristic & $\begin{array}{l}\text { The Bolina River, } \\
\text { lower course }\end{array}$ & $\begin{array}{l}\text { The Bolina River, } \\
\text { upper course }\end{array}$ & The Centuria River & The Mitręga River & The Mleczna River \\
\hline $\begin{array}{l}\text { Geographical } \\
\text { coordinates }\end{array}$ & $\begin{array}{l}\text { N } 50^{\circ} 14^{\prime} 43^{\prime \prime} \\
\text { E } 19^{\circ} 06^{\prime} 02^{\prime \prime}\end{array}$ & $\begin{array}{l}\text { N } 50^{\circ} 13^{\prime} 48^{\prime \prime} \\
\text { E } 19^{\circ} 05^{\prime} 08^{\prime \prime}\end{array}$ & $\begin{array}{l}\text { N } 50^{\circ} 24^{\prime} 52^{\prime \prime} \\
\text { E } 19^{\circ} 29^{\prime} 12^{\prime \prime}\end{array}$ & $\begin{array}{l}\text { N 502 } 26^{\prime} 02.9^{\prime \prime} \\
\text { E } 19^{\circ} 17^{\prime} 58.3^{\prime \prime}\end{array}$ & $\begin{array}{l}\text { N } 50^{\circ} 06^{\prime} \text { 58.4"; } \\
\text { E } 19^{\circ} 04^{\prime} 30.2^{\prime \prime}\end{array}$ \\
\hline $\begin{array}{l}\text { Elevation of } \\
\text { sampling } \\
\text { Sites (m a.s.1.) }\end{array}$ & 257 & 262 & 343 & 300 & 236 \\
\hline Environment & $\begin{array}{l}\text { Build-up area / } \\
\text { wasteland }\end{array}$ & $\begin{array}{l}\text { Wasteland / wood- } \\
\text { land }\end{array}$ & Woodland & Wasteland & Farmlands \\
\hline $\begin{array}{l}\text { Location / } \\
\text { region }\end{array}$ & $\begin{array}{l}\text { Upper Silesia / Sile- } \\
\text { sian Upland }\end{array}$ & $\begin{array}{l}\text { Upper Silesia / Sile- } \\
\text { sian Upland }\end{array}$ & $\begin{array}{l}\text { Nature monuments } \\
\text { „Źródła Centurii”/ } \\
\text { Kraków-Częstocho- } \\
\text { wa Upland }\end{array}$ & Silesian Upland & $\begin{array}{l}\text { Upper Silesia / Sile- } \\
\text { sian Upland }\end{array}$ \\
\hline $\begin{array}{l}\text { The part of the } \\
\text { river studied }\end{array}$ & Downstream & Upstream & Upstream / Spring & Downstream & Downstream \\
\hline Human pressure & Extreme & Very high & No impact & Low & High \\
\hline $\begin{array}{l}\text { Hydromorpho- } \\
\text { logical trans- } \\
\text { formations and } \\
\text { development }\end{array}$ & $\begin{array}{l}\text { Concrete channelled, } \\
\text { very heavy pressure } \\
\text { of mine water supply }\end{array}$ & $\begin{array}{l}\text { Channelled with } \\
\text { concrete plate; heavy } \\
\text { pressure of mine } \\
\text { water supply }\end{array}$ & Unaltered site & $\begin{array}{l}\text { Channeled, with } \\
\text { fascine-reinforced } \\
\text { banks and a dam } \\
\text { reservoir }\end{array}$ & $\begin{array}{l}\text { Channeled, with } \\
\text { fascine-reinforced } \\
\text { banks and indirect } \\
\text { supply of mine } \\
\text { waters }\end{array}$ \\
\hline $\begin{array}{l}\text { Type of river / } \\
\text { geology }\end{array}$ & $\begin{array}{l}\text { (5) Mid-altitude } \\
\text { siliceous streams that } \\
\text { have a fine-particu- } \\
\text { late substratum }\end{array}$ & $\begin{array}{l}\text { (5) Mid-altitude } \\
\text { siliceous streams that } \\
\text { have a fine-particu- } \\
\text { late substratum }\end{array}$ & $\begin{array}{l}\text { (5) Mid-altitude } \\
\text { siliceous streams that } \\
\text { have a fine-particu- } \\
\text { late substratum }\end{array}$ & $\begin{array}{l}\text { (6) Mid-altitude } \\
\text { calcareous streams } \\
\text { that have a fine-par- } \\
\text { ticulate substratum } \\
\text { on loess }\end{array}$ & $\begin{array}{l}\text { (6) Mid-altitude } \\
\text { calcareous streams } \\
\text { that have a fine-par- } \\
\text { ticulate substratum } \\
\text { on loess }\end{array}$ \\
\hline $\begin{array}{l}\text { Type of bottom } \\
\text { sediments }\end{array}$ & Silt and sand & Coal mine sludge & Sand and silt & Sand and silt & Silt and sand \\
\hline
\end{tabular}


matter. After washing four times with distilled water, the final suspension was pipetted onto cover slips, left to evaporate and mounted on glass slides using Naphrax ${ }^{\circledR}$ diatom mountant. The slides were examined using Zeiss Axio Scope A1 and Nikon Eclipse E600 light microscopes. The measurements and photographic documentation were performed using AxioVision Rel. 4.8 software. In all of the samples that were studied, a minimum of 400 valves were identified to the species or variety level and their relative abundance was determined. A number of ecological metrics were used to analyse the diatoms - the percentages of particular taxa:

$$
\mathrm{D}_{\mathrm{i}}=\frac{\mathrm{n}_{\mathrm{i}}}{\mathrm{N}} \cdot 100[\%],
$$

where $\mathrm{D}_{\mathrm{i}}$ - percentages of particular taxon ' $\mathrm{i}$ ', $\mathrm{n}_{\mathrm{i}}$ - the abundance of a particular taxon ' $\mathrm{i}$ ', $\mathrm{N}$ - the sum of all of the taxa abundances in a sample (TüMPLING \& FrIEDRICH 1999), the frequency coefficient:

$$
\mathrm{C}_{\mathrm{i}}=\frac{\mathrm{k}_{\mathrm{i}}}{\mathrm{k}} \cdot 100[\%],
$$

where $\mathrm{C}_{\mathrm{i}}-$ the frequency coefficient of particular taxon ' $\mathrm{i}$ ' [\%], $\mathrm{k}_{\mathrm{i}}$ - the number of samples with taxon ' $\mathrm{i}$ ', $\mathrm{k}$ - the number of all of the samples (species were grouped according to their frequency coefficient as euconstants $=75-100 \%$, constants $=$ $75-50 \%$, accessory $=25-50 \%$, incidental $=1-25 \%$; TrOJAN 1975), and biodiversity indices (i.e. species richness, Shannon index:

$$
\mathrm{H}^{\prime}=\sum_{\mathrm{i}=1}^{\mathrm{s}}\left(\frac{\mathrm{n}_{\mathrm{i}}}{\mathrm{N}} \log _{2} \frac{\mathrm{n}_{\mathrm{i}}}{\mathrm{N}}\right),
$$

where $\mathrm{S}$ - the number of species (species richness), $\mathrm{n}$ - the abundance of a taxon, $\mathrm{N}$ - the sum of all of the taxa abundances and the Evenness index:

$$
\mathrm{E}=\frac{\mathrm{H}^{\prime}}{\mathrm{H}_{\text {max }}^{\prime}},
$$

where $H^{\prime}$ - the Shannon index, $H^{\prime}$ max - the maximum possible value of the index $H^{\prime}$ ) were calculated (SHANNON 1948). OMNIDIA v5 software was used to calculate the percentages of diatoms in specific ecological groups. For scanning electron microscope (SEM) observations, cleaned material was pipetted onto a $25 \mathrm{~mm}$ diameter polycarbonate membrane Whatman ${ }^{\circledR}$ Nuclepore filter with a $2 \mu \mathrm{m}$ mesh, attached to aluminium stubs and sputtered with $20 \mathrm{~nm}$ of gold using a Quorum Q 150OT ES Turbo-Pumped Sputter Coater. The diatoms were observed using a Hitachi SU 8010 SEM at the Podkarpacie Innovative Research Center of the Environment (PIRCE) at the University of Rzeszów, Poland.

The diatoms that were identified served as the basis for assessing the ecological status of the rivers with the diatom index IO according to the methodology used by the national monitoring system (PiCIŃSKA-FAŁTYNOWICZ et al. 2006; PiciŃSKa-FAŁTYNOWICZ \& BŁachuta 2010; PN-EN

\begin{tabular}{|c|c|c|c|c|c|}
\hline Parameter & $\begin{array}{l}\text { The Bolina River, } \\
\text { lower course }\end{array}$ & $\begin{array}{l}\text { The Bolina River, } \\
\text { upper course }\end{array}$ & $\begin{array}{l}\text { The Centuria } \\
\text { River }\end{array}$ & $\begin{array}{l}\text { The Mitręga } \\
\text { River }\end{array}$ & $\begin{array}{l}\text { The Mleczna } \\
\text { River }\end{array}$ \\
\hline Width of the river bed (m) & $4.41-4.53$ & $7.24-7.78$ & $4.47-5.95$ & $2.87-3.39$ & $6.26-9.36$ \\
\hline Depth of the river bed (m) & $0.21-0.25$ & $0.25-0.34$ & $0.10-0.23$ & $0.40-0.59$ & $0.81-1.09$ \\
\hline Flow velocity $\left(\mathrm{m} \cdot \mathrm{s}^{-1}\right)$ & $0.40-0.51$ & $0.06-0.42$ & $0.07-0.17$ & $0.01-0.29$ & $0.16-0.21$ \\
\hline Temperature $\left({ }^{\circ} \mathrm{C}\right)$ & $15.5-29.1$ & $15.7-28.6$ & $7.5-13.6$ & $10.4-18.4$ & $14.8-25.1$ \\
\hline $\mathrm{pH}$ & $7.5-7.9$ & $7.5-7.8$ & $7.5-7.8$ & $7.3-8.1$ & $7.4-8.0$ \\
\hline Salinity (PSU) & $16.34-33.55$ & $6.57-12.25$ & $0.19-0.21$ & $0.29-0.35$ & $2.97-5.16$ \\
\hline $\begin{array}{l}\text { Dissolved oxygen } \\
\left(\mathrm{mg} \cdot \mathrm{dm}^{-3}\right)\end{array}$ & $5.13-9.69$ & $4.65-7.09$ & $4.89-6.61$ & $4.62-6.12$ & $0.69-4.82$ \\
\hline Conductivity $\left(\mu \mathrm{S} . \mathrm{cm}^{-1}\right)$ & $22700-44600$ & $9130-17020$ & $250-270$ & $380-460$ & $4120-7160$ \\
\hline $\begin{array}{l}\text { Total dissolved solids } \\
\left(\mathrm{mg} \cdot \mathrm{dm}^{-3}\right)\end{array}$ & $11360-23300$ & $4570-8510$ & $110-140$ & $180-220$ & $2050-3570$ \\
\hline Chlorides $\left(\mathrm{mg} \cdot \mathrm{dm}^{-3}\right)$ & $7528-17028$ & $2823-5590$ & $8-20$ & $18-26$ & $1340-1970$ \\
\hline 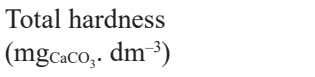 & $2268-4858$ & $1072-1920$ & $160-225$ & $175-330$ & $405-560$ \\
\hline Calcium (mg.dm $\left.{ }^{-3}\right)$ & $548-1310$ & $328-687$ & $55-60$ & $69-94$ & $101-158$ \\
\hline Magnesium (mg.dm $\left.{ }^{-3}\right)$ & $225-670$ & $124-270$ & $4-22$ & $1-30$ & $38-60$ \\
\hline Alkalinity $\left(\mathrm{mg}_{\mathrm{CaCO}_{3}} \cdot \mathrm{dm}^{-3}\right)$ & $230-320$ & $275-380$ & $75-110$ & $165-250$ & $240-275$ \\
\hline Phosphates (mg.dm ${ }^{-3}$ ) & $0.05-0.10$ & $0.02-0.14$ & $0.00-0.11$ & $0.08-0.24$ & $0.16-3.84$ \\
\hline Ammonium (mg.dm ${ }^{-3}$ ) & $1.25-12.12$ & $0.62-1.00$ & $0.00-0.23$ & $0.26-0.36$ & $0.23-1.21$ \\
\hline Nitrates $\left(\mathrm{mg} \cdot \mathrm{dm}^{-3}\right.$ ) & $4.43-10.63$ & $0.00-79.74$ & $0.00-11.96$ & $0.89-15.95$ & $5.32-10.19$ \\
\hline Nitrites (mg.dm ${ }^{-3}$ ) & $2.49-9.96$ & $0.68-1.44$ & $0.00-0.01$ & $0.11-0.24$ & $0.20-0.73$ \\
\hline $\operatorname{Iron}\left(\mathrm{mg} \cdot \mathrm{dm}^{-3}\right)$ & $0.12-0.39$ & $0.13-0.88$ & $0.03-0.65$ & $0.25-0.78$ & $0.26-1.46$ \\
\hline Sulfates (mg.dm ${ }^{-3}$ ) & $320-550$ & $352-770$ & $35-44$ & $49-66$ & $200-272$ \\
\hline
\end{tabular}
13946 2014; PN-EN 14407 2014; ZGRUNDO et al. 2018).

The identifications were based on the following

Table 2. The physical and chemical parameters of the water and the morphology of the riverbed. 


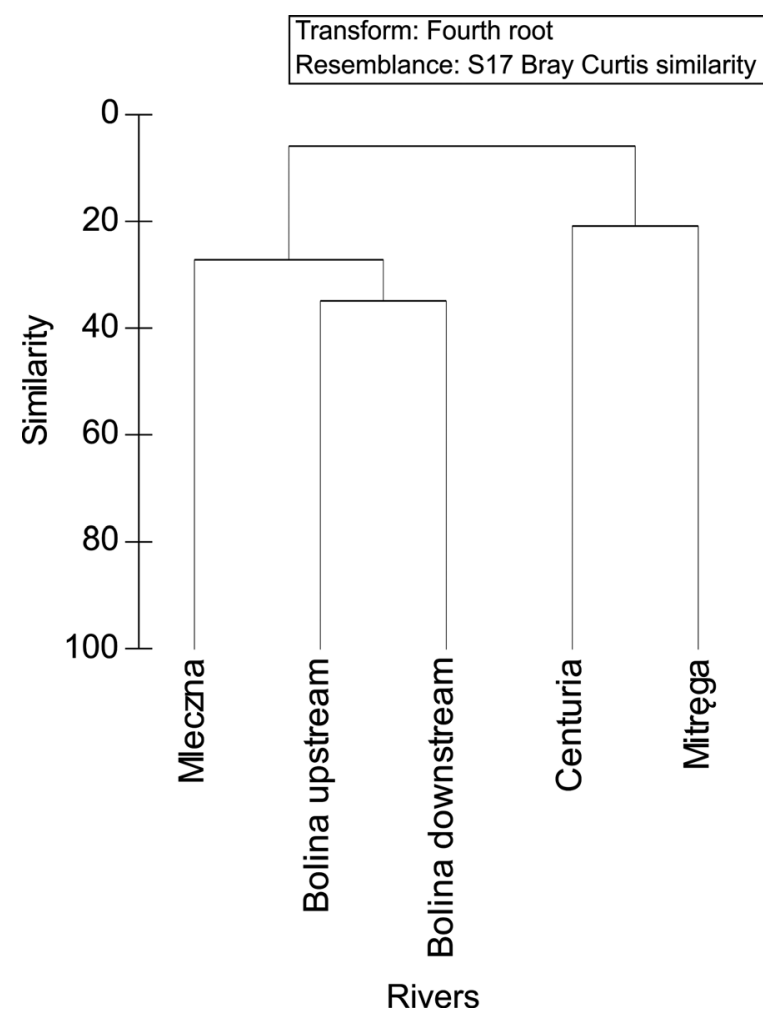

Fig. 2. A Bray-Curtis similarities dendrogram of the sampling sites with respect to the diatom flora and the abundance of taxa.

references: KRAMMER \& LANGE-BERTALOT 1986, 1988, 1991a, 1991b; Lange-Bertalot \& Metzeltin 1996; WitKowski et al. 2000; Krammer 2000, 2002, 2003; LANGE-Bertalot 2001; LeVkov 2009; LeVkov et al. 2013, 2016; LANGE-Bertalot et al. 2011; Hofmann et al. 2011; BĄK et al. 2012; CANTONATI et al. 2017.

Data analysis. The significance of the differences in the median values of the environmental variables among the sampling sites in the rivers was calculated using the Kruskal-Wallis one-way ANOVA and the multiple comparison post hoc tests using Statistica version 13.1. The value of the environmental variables did not reveal a normal distribution according to the Lilliefors test of normality, which justified the use of a non-parametric test. Canonical ordination analyses for relating diatom species composition to environmental variables were carried out using CANOCO for Windows version 4.5 (Ter BraAK \& Šmilauer 2002). The chosen system for species examination used detrended correspondence analysis (DCA) and the gradient length, which exceeded 4 standard deviations. Therefore, a unimodal direct ordination canonical correspondence analysis (CCA) with a forward selection was used to reduce the large set of environmental variables. The relationship between diatom species and environmental variables was evaluated using the Monte Carlo permutation test (499 permutations). The CCA was performed based on both the log-transformed species and environmental data.

The structures of the diatom flora and the relationships between their assemblages in the rivers that were studied were analysed using the statistical multivariate methods provided by the PRIMER software (Plymouth Routines in Multivariate Ecological Research; Clarke \& WARWICK 2001). Discrimination between the groups of sites with similar diatom populations was aided by cluster analysis. The ranked similarity matrices were constructed using the Bray-Curtis similarity measure with a fourth root transform and group-average sorting, i.e. the average similarity indices for successively created group of sites (LANCE \& WiLLIAMS 1967).

\section{RESULTS}

Environmental conditions of the investigated rivers The salinity, conductivity, total dissolved solids, total hardness, concentration of chlorides, calcium, magnesium, ammonium and nitrites in the water were extremely high at the sampling site with the highest degree of anthropogenic pressure, i.e. in the lower course of the Bolina River (Tables 1 and 2). However, the concentration of sulfates, nitrates and alkalinity were higher in the upper course of the river. Because of the discharge of the coal mine waters into the Bolina River, the salinity ranged from 16.34 to 33.55 PSU (Table 2). The salinity values of the lower course of the Bolina River exceeded the maximum salinity that was recorded for the Baltic Sea (SATBAŁTYK 2018). By contrast, the lowest values of most of the physical and chemical parameters of the water were recorded in the site that is not impacted by anthropogenic activity (the Centuria River) except for the dissolved oxygen or $\mathrm{pH}$. Both rivers (Bolina and Centuria) represent the abiotic type 5 - mid-altitude siliceous streams that have a fine-particulate substratum. When the two other rivers of the same abiotic type (type 6 - mid-altitude calcareous streams that have a fine-particulate substratum on loess, PICIŃSKA-FAŁTYNOWICZ \& BŁACHUTA 2010) but with different anthropogenic pressure were compared, lower values of the physical and chemical parameters were obtained in the Mitręga River (low anthropogenic pressure) than in the Mleczna River (high anthropogenic pressure).

\section{Diatom assemblages in the rivers that were studied} The diatom taxa (species and varieties) that were identified in the microphytobenthos of the rivers that were studied were represented by 55 genera. The centrics were represented by six genera with eight species and varieties, while the 49 pennate genera comprised 150 species and varieties. Only two of the identified taxa were euconstants (taxa occurring in $75-100 \%$ of the samples that were analysed) and these were Navicula gregaria Donkin and Planothidium frequentissimum (Lange-Bertalot) Lange-Bertalot. The constants (occurrences in $50-75 \%$ of the samples) included seven taxa: Achnanthidium minutissimum (Kützing) Czarnecki, Ctenophora pulchella (Ralfs ex Kützing) D.M.Williams et Round, Cyclotella meneghiniana Kützing, Gyrosigma attenuatum (Kützing) Rabenhorst, Hippodonta capitata (Ehrenberg) Lange-Bertalot, Metzeltin et Witkowski, Planothidium delicatulum (Kützing) Round et Bukhtiyarova, Pleurosigma salinarum Grunow in Cleve et Grunow. The 


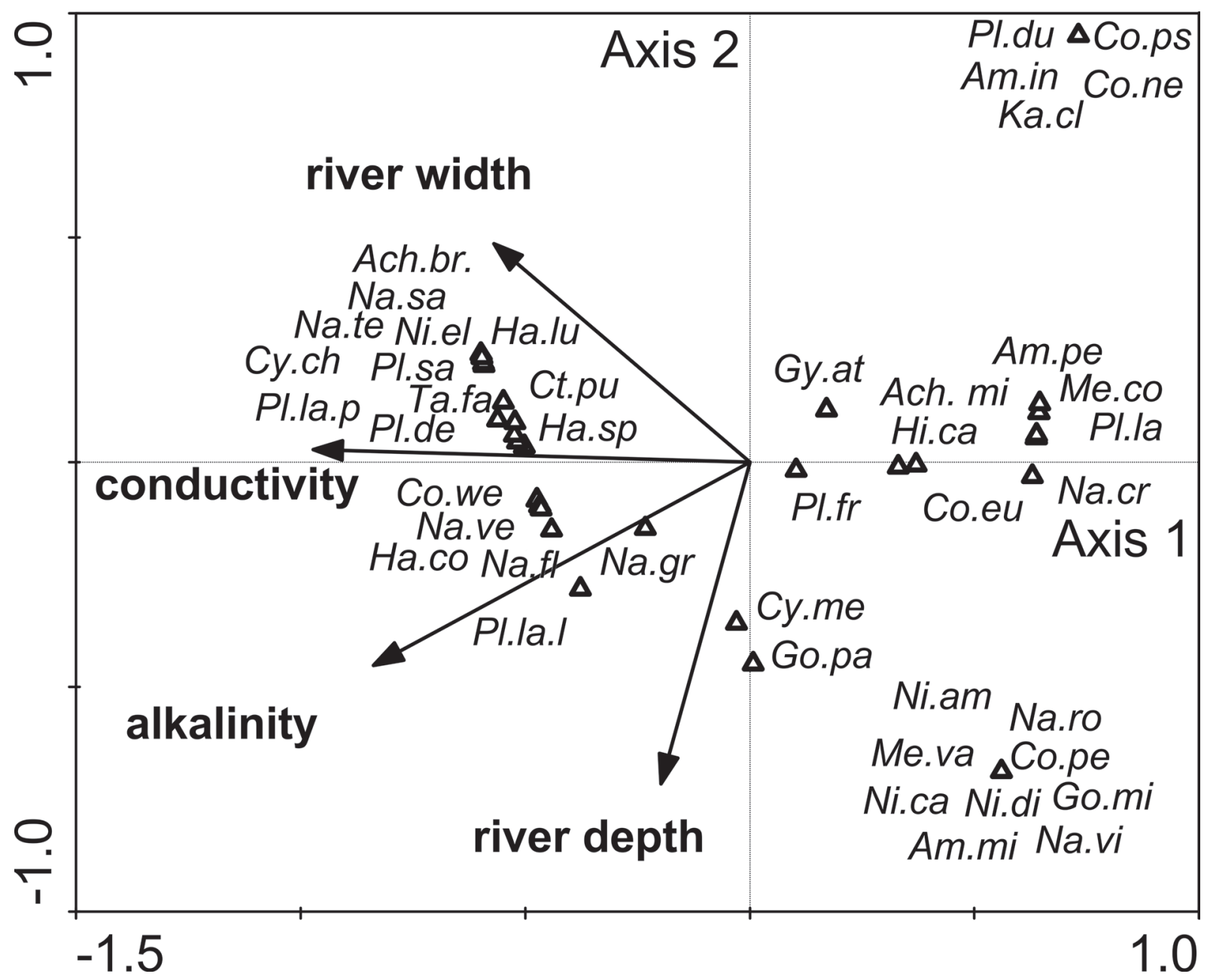

Fig. 3. Ordination diagram (bioplot) based on the canonical correspondence analysis (CCA) of diatom data and environmental variables of the studied rivers. Abbreviations: (Ach.br.) Achnanthes brevipes var. intermedia, (Ach.mi) Achnanthidium minutissimum, (Am.in) Amphora inariensis, (Am.mi) Amphora minutissima, (Am.pe) Amphora pediculus, (Co.eu) Cocconeis euglypta, (Co.ne) Cocconeis neothumensis, (Co.pe) Cocconeis pediculus, (Co.ps) Cocconeis pseudothumensis, (Co.we) Conticribra weissflogii, (Ct.pu) Ctenophora pulchella, (Cy.ch) Cyclotella choctawhatcheeana, (Cy.me) Cyclotella meneghiniana, (Go.mi) Gomphonema minutum, (Go.pa) Gomphonema parvulum, (Gy.at) Gyrosigma attenuatum, (Ha.co) Halamphora coffeiformis, (Ha.lu) Halamphora luciae, (Ha.sp) Haslea spicula, (Ka.cl) Karayevia clevei, (Me.co) Meridion constrictum, (Me.va) Melosira varians, (Na.cr) Navicula cryptotenella, (Na.fl) Navicula flandriae, (Na.gr) Navicula gregaria, (Na.ro) Navicula rostellata, (Na.sa) Navicula salinarum var. minima, (Na.te) Navicula tenelloides, (Na.ve) Navicula veneta, (Na.vi) Navicula viridula, (Ni.am) Nitzschia amphibia, (Ni.ca) Nitzschia capitellata, (Ni.di) Nitzschia dissipata, (Ni.el) Nitzschia elegantula, (Pl.de) Planothidium delicatulum, (Pl.du) Planothidium dubium, (Pl.fr) Planothidium frequentissimum, (Pl.la) Planothidium lanceolatum, (Pl.la.l) Pleurosira laevis var. laevis, (Pl.la.p) Pleurosira laevis var. polymorpha, (Pl.sa) Pleurosigma salinarum, (Ta.fa) Tabularia fasciculata.

accessory species (occurrences in $25-50 \%$ of the samples) comprised 29 taxa; the largest number of taxa (120) was classified as incidental. Their frequency coefficient was less than $25 \%$ of the samples that were analysed.

Similarities between the rivers with respect to the diatom flora

An analysis of the similarities between the sampling sites with respect to the diatom assemblages and the abundance of taxa was aided by using the Bray-Curtis similarity measure. The resulting dendrogram shows two groups of rivers with an approximately $30 \%$ similarity (Fig. 2).

Although the similarity of diatom assemblages was not very high, the rivers that were studied seem to cluster together predominantly due to anthropogenic pressure. The first group comprised sites with a strong impact - the salinised rivers (Mleczna and Bolina). The diatom assemblages from these sites were predominantly composed of taxa that prefer brackish or brackish-marine water: Pleurosira laevis var. laevis (Ehrenberg) Compère and var. polymorpha Compère, Ctenophora pulchella, Achnanthes brevipes var. intermedia (Kützing) Cleve, Halamphora coffeiformis (C.Agardh) Levkov, H. luciae (Cholnoky) Levkov, Navicula salinarum f. minima Kolbe, Gyrosigma attenuatum, Haslea spicula (Hickie) Bukhtiyarova and Pleurosigma salinarum. The second distinct group comprised the sites with a minimal or weak anthropogenic impact (Centuria and Mitręga). The taxa that distinguished this group from the previous one primarily prefer fresh-brackish water. The other ecological preferences of the taxa do not significantly differentiate the rivers that were studied and were clustered in two 


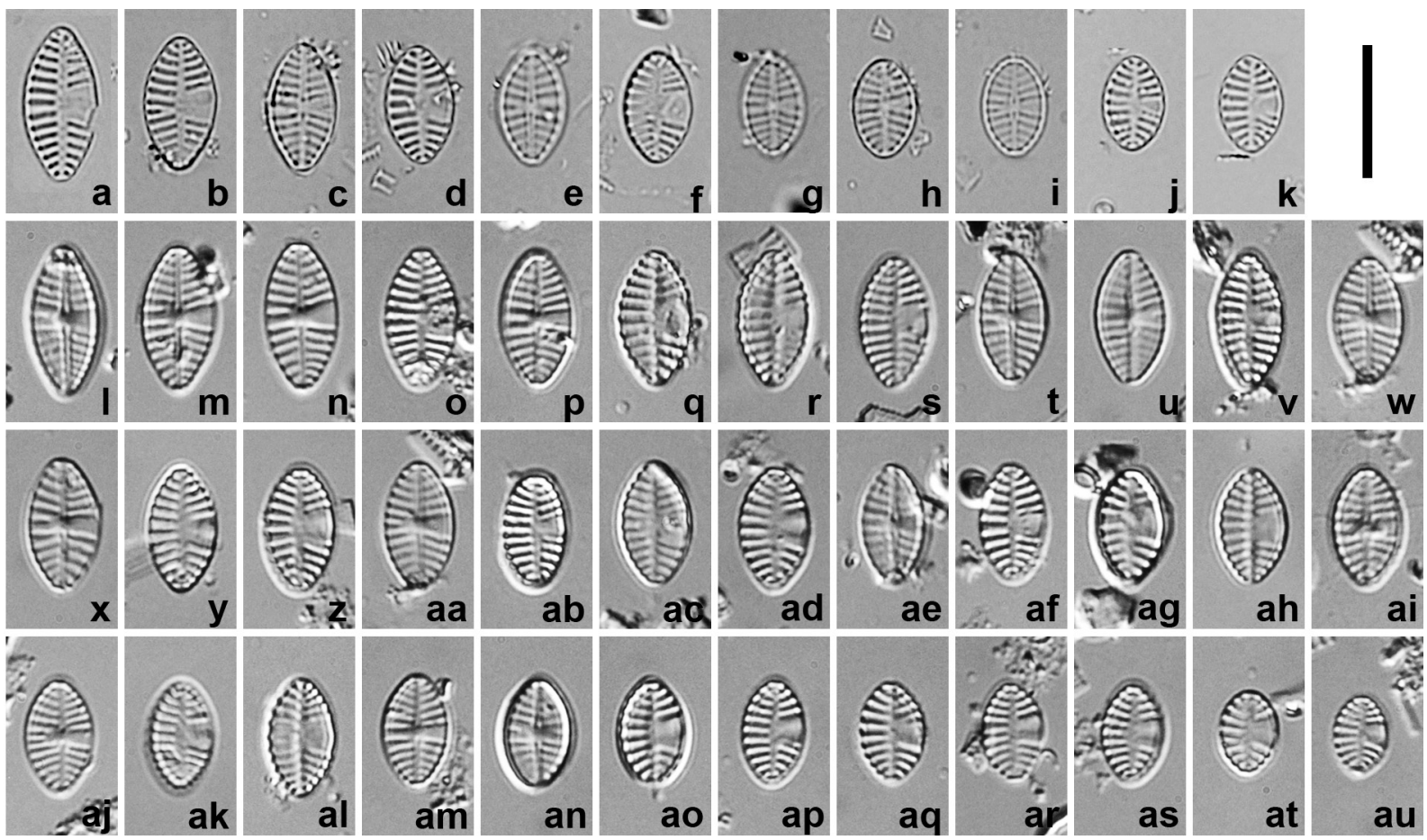

Fig. 4. Planothidium nanum sp. nov. LM images. Size diminution series. In the valve views, the variations in the size of the type population are shown. Fig. $4 \mathrm{~d}$ and $4 \mathrm{e}$ are of the holotype. Scale bar $10 \mu \mathrm{m}$.

groups, but some differences were still visible. In the Bolina and Mleczna Rivers, species that are characteristic of eutrophicated waters and for $\alpha$-mesosaprobic zone dominated. The species that were present in the Centuria River were typical of those that prefer oligotrophic and oligosaprobic waters as well as those that are highly tolerant to trophic conditions, the saprobic status and nutrient content (the dominants included Planothidium dubium (Grunow) Round et Bukhtiyarova, Cocconeis pseudothumensis Reichardt, C. neothumensis Krammer, Karayevia clevei (Grunow) Bukhtiyarova, Amphora inariensis Krammer and Achnanthidium minutissimum var. minutissimum). The taxa that were present in the Mitręga River were typical cosmopolitan forms that are found in various types of water, but that quite frequently occur in waters with an elevated trophic and saprobic status (no distinct dominants).

\section{Biodiversity of the diatom flora in the rivers that were studied}

The biodiversity of the flora in the rivers with a minimal or weak anthropogenic impact (Centuria and Mitrega) was high, whereas in those that were strongly affected - the salinised rivers (Mleczna and Bolina) - it was quite low. The Bolina and Mleczna sites, which were characterised by the highest salinity (7-12 PSU in the upstream and 16-34 PSU downstream of the Bolina River and the 3-5 PSU of the Mleczna River), had a relatively low taxonomic richness (23 and 32 taxa in the upstream and downstream courses of the Bolina River, respectively, and 23 taxa in the Mleczna River). The initial stretch of the Centuria River and the downstream section of the
Mitręga River had a much higher taxonomic richness (55 and 74 taxa, respectively).

The Shannon ( $\mathrm{H}$ ' for the $\log$ s to the base 2 ) and the Evenness indices were almost two-fold higher in the rivers that were not salinised (Centuria 4.26 and 0.74 , Mitręga 5.36 and 0.87 ) than in the salinised rivers (2.23 and 0.49 in the upstream and 2.04 and 0.41 in the downstream of the Bolina River and 2.84 and 0.63 in the Mleczna River).

The diatoms that were identified served as the basis for assessing the ecological status of the rivers with the diatom index IO according to the methodology that is used by the state monitoring system. The status of the Bolina River, in both the downstream and upstream course was considered to be poor, whereas the state monitoring system classified the Bolina (both ecological and chemical) as bad. The diatom index that was applied to the remaining rivers confirmed the ecological status classification from the state monitoring - the Mleczna, Mitręga, and Centuria Rivers were classified as representing a poor, moderate and good ecological status, respectively. The lists of the indicator species that were used by the state monitoring system until 2017 did not include the brackish species Pleurosira laevis, which was dominant in the Bolina and Mleczna Rivers. After adding $P$. leavis to the list of indicator species in 2018, the results of the assessment of the ecological status of the Bolina and Mleczna Rivers was improved by one level. According to the classification that was developed by DENYS (1991) and VAN DAM et al. (1994), this species is eutrophic and oligosaprobic. However, as was shown by results of our studies, the species is able to tolerate 

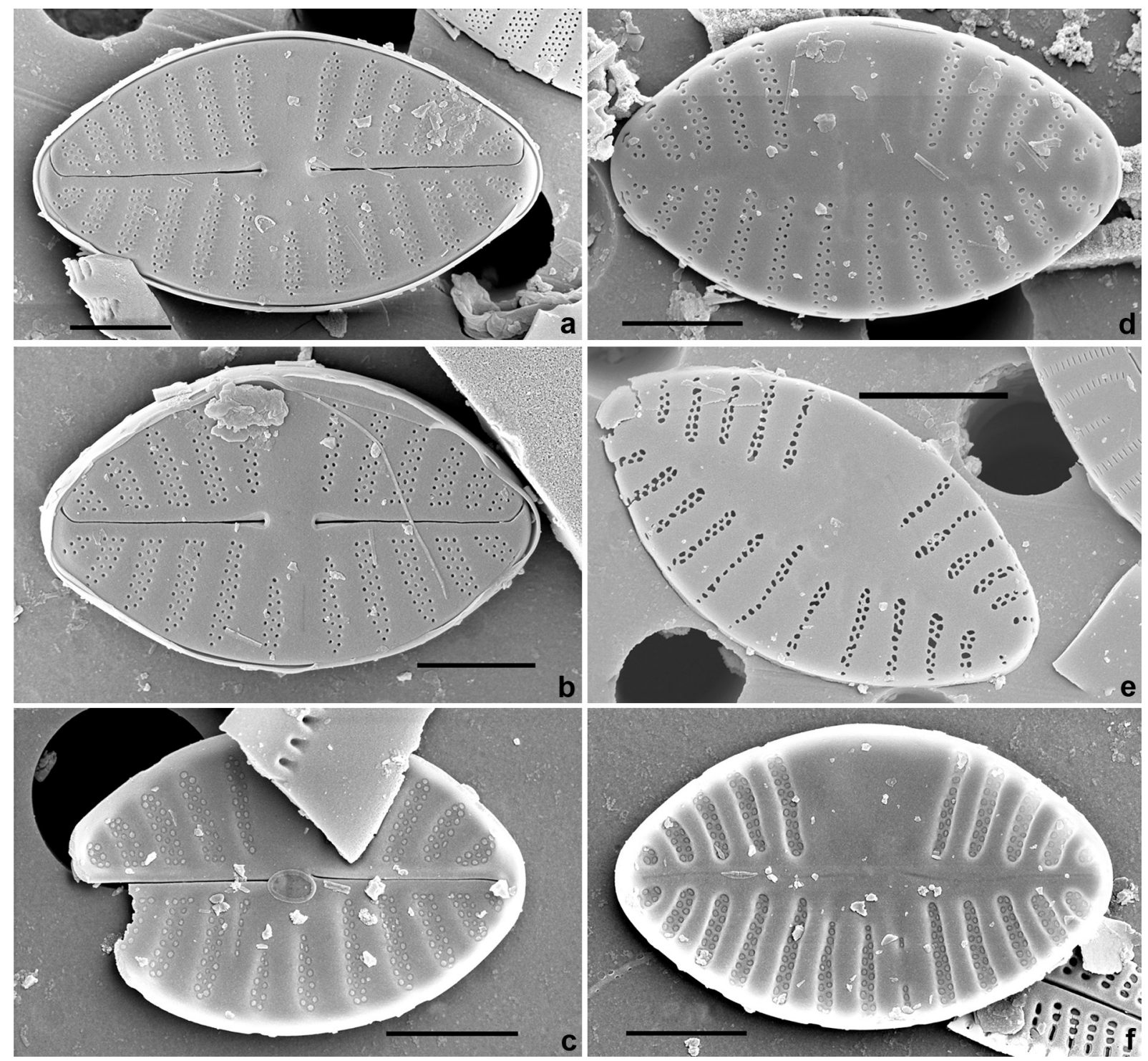

Fig. 5. Planothidium nanum sp. nov. SEM images. $(\mathrm{a}-\mathrm{c})$ raphe valves: $(\mathrm{a}-\mathrm{b})$ external view, note the somewhat expanded external proximal central raphe endings; (c) internal view, note the internal proximal raphe endings that are bent in the opposite directions. (d-f) sternum valves: (d-e) external view, (f) internal view, note the presence of a unilateral central area. Scale bars $2 \mu \mathrm{m}$.

considerably elevated levels of nutrients and organic pollutants and is capable of forming very abundant populations in rivers with a periodically, and significantly, elevated salinity due to discharges of saline mine water.

During the species identification, one new species for Poland - Navicula flandriae Van de Vijver et Mertens in BEAUGER et al. (2015) and one species that is new to science were found - Planothidium nanum sp. nov., a description of which follows. In recent years, the genus Planothidium has been in the focus of both morphological and molecular studies. Currently, it comprises about 60 accepted species. Over the last five years (2014-2019), 32 new species were described, of which 31 are freshwater and only one is marine.

The results of the canonical correspondence analysis (CCA)

A canonical correspondence analysis (CCA) revealed that the first and second axes explain $70.0 \%$ of species variance and $78.5 \%$ of the variance in the species and environment relationship. Conductivity, alkalinity, river width and depth were most associated (statistically significant according to the forward selection results) with the diatom taxa distribution (Fig. 3). The CCA analysis was significant (Monte Carlo test on the first canonical axis, $\mathrm{F}-$ ratio $=11.757, \mathrm{P}-$ value $=0.002$; test of significance of all of the canonical axes, $\mathrm{F}-$ ratio $=30.897$, P-value $=0.002$ ). The CCA analysis showed that Achnanthes brevipes var. intermedia, Halamphora coffeiformis, Halamphora luciae, Haslea spicula, Navicula salinarum var. minima, Pleurosigma salinarum, Pleurosira laevis var. laevis, and P. laevis var. polymorpha were associated with higher riverine conductivity and alkalinity (Fig. 3). By contrast, Achnanthidium minutissimum, Amphora inariensis, Cocconeis euglypta Ehrenberg, Hippodonta 
capitata, Meridion constrictum Ralfs, Planothidium lanceolatum (Brébisson ex Kützing) Lange-Bertalot, and Navicula cryptotenella Lange-Bertalot in Krammer \& Lange-Bertalot were associated with lower conductivity and alkalinity. Achnanthidium minutissimum, Cocconeis pediculus Ehrenberg, Gomphonema minutum (C.Agardh) C.Agardh, Melosira varians C.Agardh, Nitzschia amphibia Grunow, N. dissipata (Kützing) Rabenhorst, and Navicula viridula (Kützing) Ehrenberg were associated with lower water conductivity and river width (Fig. 3).

\section{Description of the new species Planothidium nanum sp. nov. Bąk, Kryk et Halabowski (Figs 4-5)}

Description: Light microscopy, Figs 4a-au - Valves consistently elliptical with obtusely rounded ends that were never protracted. Length 5.5-11.5 $\mu \mathrm{m}$, breadth 4.0-5.5 $\mu \mathrm{m}$.

Rapheless valve: Raphe filiform, straight with slightly expanded central pores and distinctly curved distal endings. Axial area very narrow, straight. Central area is asymmetrical due to the two more widely spaced central striae on the primary side than on the secondary side of the valves, where one or two shortened striae are present. Striae slightly radiate throughout the valves, $12-14$ in $10 \mu \mathrm{m}$.

Scanning electron microscopy, external view (Figs $5 a-b)$ : Raphe straight with slightly expanded central ends, terminal fissures unilaterally bent to the mantle. Striae moderately radiate becoming strongly radiate near the ends. Transapical striae composed of 2-3 series of round areolae. Areola density counted in a single series is ca. $55-65$ in $10 \mu \mathrm{m}$.

SEM internal view (Fig. 5c): Central raphe ends not coaxial but deflected to the opposite sides. Distal ends with small helictoglossae. Central nodule together with the virgae features a high profile raised above the troughs containing the bi- or triseriate occluded areolae.

Rapheless valve: A depression is visible in LM as a broad space between two central striae on primary side. Cavum structure is absent. Axial area narrow, straight or slightly broader towards the central area.

SEM external view (Figs 5d-e): Striae consisting of 1-2 series of areolae; virgae considerably broader than striae. The surface on the valve is entirely smooth. SEM internal view, see Fig. 5f.

Type: Poland, Upper Silesia, Centuria River, 50²4'52"N, 19²9'12"E, 11 July 2017.

Holotype (assigned here): Slide no. 25760 in Coll. Andrzej Witkowski, Institute of Marine and Environmental Sciences, University of Szczecin (SZCZ), the holotype is represented by Figs 4d and 4e.

Type locality: Centuria River located in southern Poland that belongs to the Upper Vistula River system; epipsammic sample from bottom sediment.

Etymology: The Latin epithet means dwarf.

Distribution: Known only from the type locality.
Ecology: Freshwater, slightly alkaline with low conductivity, oligotrophic and oligosaprobic waters. The species co-occurring with species that are typical of oligotrophic and oligosaprobic waters as well as those that are highly tolerant of trophic conditions, saprobic status and nutrient content (in the order of domination): Karayevia clevei, Cocconeis pseudothumensis, Planothidium dubium, Cocconeis neothumensis, Amphora inariensis, Achnanthidium minutissimum, Amphora pediculus (Kützing) Grunow in Schmidt, Ellerbeckia arenaria (G.Moore ex Ralfs) R.M. Crawford, Reimeria sinuata (W.Gregory) Kociolek et Stoermer, Staurosirella lapponica (Grunow) D.M. Williams et Round, Staurosirella pinnata (Ehrenberg) D.M.Williams et Round, Cocconeis pseudolineata (Geitler) Lange-Bertalot in Werum et Lange-Bertalot, Hippodonta capitata, Navicula cryptotenella, Platessa conspicua (Ant.Mayer) Lange-Bertalot in Krammer et Lange-Bertalot, Geissleria acceptata (Hustedt) Lange-Bertalot et Metzeltin, Gomphonema clavatulum Reichardt, Gomphonema subclavatum (Grunow) Grunow, Meridion constrictum, Odontidium mesodon (Kützing) Kützing, Planothidium lanceolatum, Psammothidium bioretii (H.Germain) Bukhtiyarova et Round, Reimeria uniseriata S.E.Sala, J.M.Guerrero et M.E.Ferrario, Sellaphora bacillum (Ehrenberg) D.G.Mann, Ulnaria ulna (Nitzsch) Compère and other species.

\section{Comparison the new species with morphologically related taxa}

The small size of Planothidium nanum and its elliptical outline combined with the very widely spaced central striae on the sternum valve (sinus) and the widely spaced central striae on the raphe valve should clear up any confusion with other species. However, the taxa that were most similar to the new species are $P$. frequentissimum, P. dubium, P. rostratoholarcticum Lange-Bertalot et Bąk in Bąk et Lange-Bertalot, P. minutissimum (Krasske) E.A.Morales, P. granum (M.H.Hohn et Hellerman) Lange-Bertalot and $P$. reichardtii Lange-Bertalot et Werum. The new species differs from $P$. frequentissimum and $P$. rostratoholarcticum by the absence of a cavum (P. nanum has a sinus). It differs from $P$. reichardtii, $P$. granum and $P$. dubium by the shape of its ends-subrostrate vs rounded in $P$. nanum. In addition, $P$. dubium has larger valves (length 10-20 $\mu \mathrm{m}$, width 5.0-7.5 $\mu \mathrm{m}$ ) and $P$. granum is generally narrower, $3.6-4.2 \mu \mathrm{m}$ (vs length 5.5-11.5 and width 4.0-5.5 $\mu \mathrm{m}$ in P. nanum). New species differs from $P$. minutissimum in its valve outline - rhombic- to elliptic-lanceolate in P. minutissimum and elliptical in $P$. nanum and by being smaller in size than P. minutissimum, i.e. length $6.0-8.5 \mu \mathrm{m}$ and width $3.0-3.5 \mu \mathrm{m}$, and also by the striae density $-16-18 / 10$ $\mu \mathrm{m}$ (vs $12-14 / 10 \mu \mathrm{m}$ in P. nanum).

Navicula flandriae Van de Vijver et A.Mertens - first record for Poland (Figs 6a-p)

LM and SEM examinations of the samples that had been 


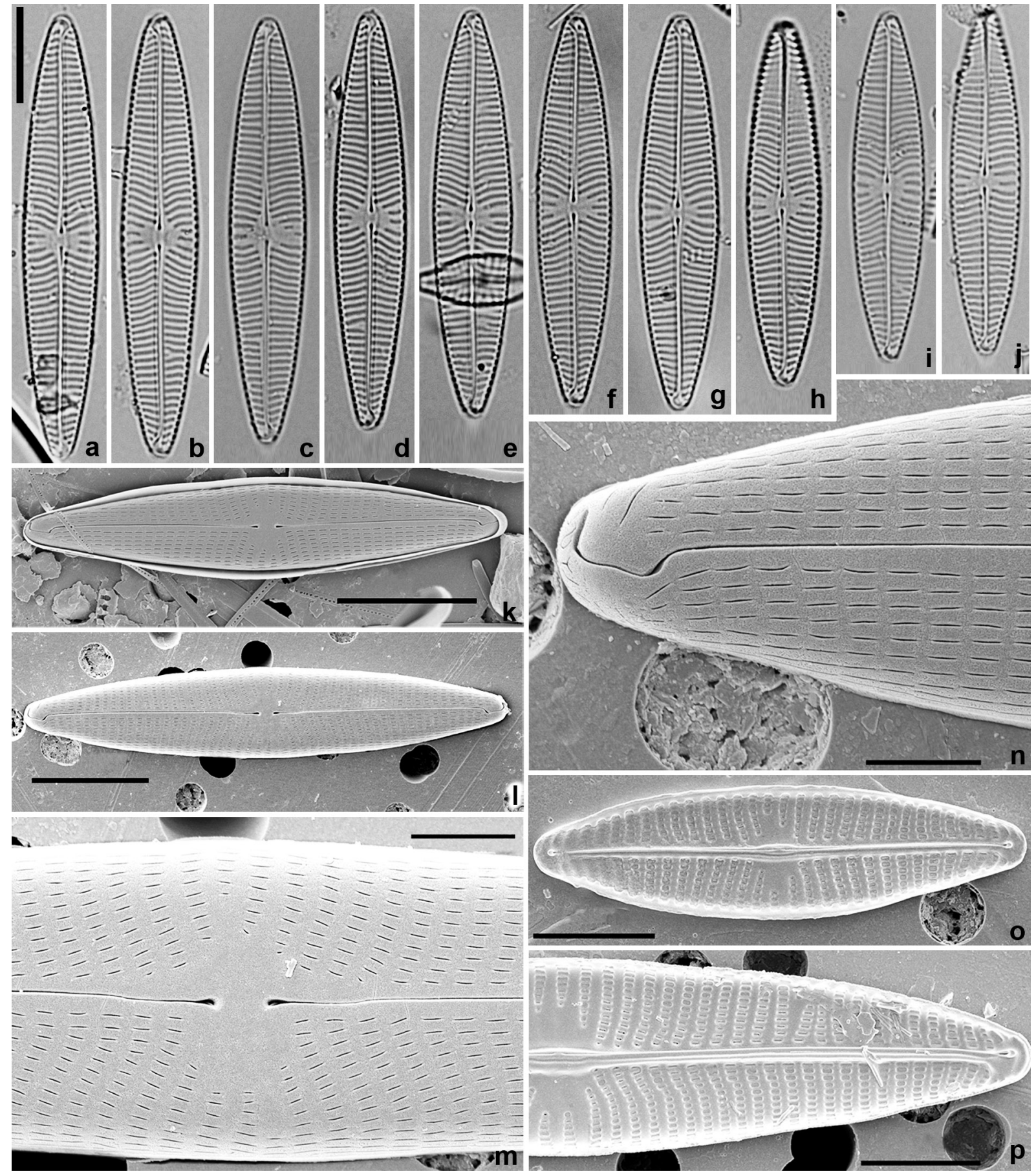

Fig. 6. Navicula flandriae Van de Vijver \& A.Mertens. (a-j) Size diminution series in the LM images. Scale bar $10 \mu \mathrm{m}$. (k-p) SEM images: $(\mathrm{k}-1)$ external view of an entire valve; $(\mathrm{m})$ close-up of the central area; $(\mathrm{n})$ detail of a valve apex showing the curved terminal raphe endings; (o) internal view of an entire valve; (p) close-up of the central area and valve apex. Scale bars (k, l) $10 \mu \mathrm{m},(\mathrm{m}, \mathrm{n}) 2 \mu \mathrm{m},(\mathrm{o}, \mathrm{p}) 5 \mu \mathrm{m}$.

collected from the Mleczna and Bolina Rivers revealed the occurrence of $N$. flandriae. The species was described in 2015 from Flanders (Flandria), the northern region in Belgium where this species was observed in several rivers and canals (i.e. Leopoldkanaal, Oostpolderkreek) in alkaline waters with a high conductivity. Navicula flandriae was very abundant in the Mleczna River (38\% relative abundance) and a few specimens occurred in the downstream of the Bolina River (1.2\%). The valves were 35-46 $\mu \mathrm{m}$ long, 7-8 $\mu \mathrm{m}$ wide with 13-14 striae per $10 \mu \mathrm{m}$ (Fig. 6a-j). According to VAN DE VIJVER and Mertens in Beauger et al. (2015), the valves are 35-65 $\mu \mathrm{m}$ long, 7.0-9.5 $\mu \mathrm{m}$ wide with 12-13 striae per $10 \mu \mathrm{m}$. The specimens that were found in Poland were characterised by a higher stria density in both the smaller and larger specimens. The LM and SEM observations (Fig. $6 \mathrm{k}-\mathrm{p}$ ) were consistent with those given by BEAUgER et al. (2015). Navicula flandriae was accompanied by Pleurosira laevis var. laevis, Gomphonema parvulum (Kützing) Kützing, Cyclotella meneghiniana, 
Halamphora coffeiformis, Cocconeis placentula var. placentula Ehrenberg, Navicula perminuta Grunow in Van Heurck, Planothidium delicatulum, Conticribra weissflogii (Grunow) Stachura-Suchoples et D.M.Williams, Navicula gregaria, Navicula veneta Kützing, Ctenophora pulchella, Haslea spicula, Nitzschia palea var. palea (Kützing) W.Smith - as the most abundant taxa in the Mleczna River.

Navicula flandriae was recently observed during routine monitoring in the province of Zuid-Holland (in: Hoofdwatergang Boutweg and Gemaal de Biersum Schuddebeursedijk) and the province of Zeeland (in: Boezem K van Steelandpolder and Goese Polder; AdriEnNe MERTENS, personal communication) in the Netherlands. In 2015 and 2016, N. flandriae was recorded in Egyptian inland waters (the Damietta Branch of the Nile River), which area $\mathrm{N}$ and $\mathrm{P}$ enriched and eutrophic (CANTONATI et al. 2016). These data indicate that it may be a widely distributed species that occurs in nutrient-rich waters that are usually accompanied by a high-conductivity. Navicula flandriae has similarities to several quite commonly occurring taxa such as $N$. tripunctata (O.F.Müller) Bory in Bory de Saint-Vincent, $N$. recens (Lange-Bertalot) Lange-Bertalot in Krammer et Lange-Bertalot, N. margalithii Lange-Bertalot in Krammer et Lange-Bertalot, N. korzeniewskii Witkowski, Lange-Bertalot et Metzeltin or N. radiosa Kützing. It is highly probable that it was wrongly identified in Polish waters and confused with the above-mentioned species. Detailed descriptions of its morphological differences are provided by BEAUGER et al. 2015.

\section{DISCUSSION}

Decrease in diatom biodiversity and taxonomic richness The diatom flora at all the five sampling sites closely reflected the extent of the anthropogenic alteration of the environment and habitat. Our results show a decrease in both the biodiversity and taxonomic richness of the diatom assemblages that occurred in the rivers that are affected by mining activity, which was more than two-fold lower than in the rivers with a weak activity. Although it is well known that salinity can have a strong influence on the distribution of diatom species (CHOLNOKY 1968), the actual importance of this factor has not yet been precisely circumscribed at regional scales with a sufficient number of samples (PoTAPOVA \& Charles 2003). To date, there have been no studies that compare diatom assemblages and their biodiversity in salt-polluted rivers with the more natural rivers in the region of Upper Silesia. However, some research was recently conducted in adjacent regions. In the industrial water biotopes of three small water reservoirs that have a high salinity in southern Poland that are connected to the Bobrza River, Kielce Upland, that had conductivity that ranged from 711 to $865 \mu \mathrm{S} . \mathrm{cm}^{-1}$ (seven samples), only 36 diatom taxa from 24 genera were identified, of which only 16 taxa were recognised as being species that are common in central Europe inland waters and the assemblages were characteristic for alkaliphilous, mesotraphentic and eutraphentic and $\beta$-mesosaprobous waters (MALINOWSKA-GNIEWOSZ et al. 2018). In our study, the salt-polluted rivers were characterised by a similarly low number of identified diatom taxa (23 to 32 taxa in the upstream and downstream sites of the Bolina River, respectively), and 23 taxa in the Mleczna River and the diatom flora was characteristic for eutrophicated and $\alpha$-mesosaprobic waters, whereas the Centuria and Mitręga Rivers were characterised by a higher taxonomic richness (55 and 74 taxa, respectively). It is worth mentioning that our research showed a similar decreasing trend in the biodiversity of the salt-polluted rivers compared to the rivers with weak pollution, i.e. the Shannon index decreased from 4.26 and 5.36 (Centuria River and Mitręga River) to only 2.23 and 2.84 (Bolina River and Mleczna River). Based on this, elevated salinity in rivers can cause a decrease in the aquatic biodiversity of diatom assemblages. Like Poland, the Czech part of Upper Silesia has a long mining history. ČECHÁKOvá et al. (2014) analysed selected groups of plants and animals such as amphibians, aquatic molluscs, other macroinvertebrates, diatoms and aquatic plants in polluted (including post-industrial salinisation) subsidence reservoirs. The conductivity of the reservoirs that were studied at specific sites was significantly higher than in our studies (exceeding $1500 \mu \mathrm{S} . \mathrm{cm}^{-1}$ ) and the conclusion was that increased levels of salts in the affected areas result in a decrease in aquatic biodiversity and have a negative effect on different groups of plants and animals (ČECHÁKoví et al. 2014). More studies that compared changes in diatom assemblages in terms of land use were carried out in South Africa (PAN et al. 2004; TAYLOR et al. 2005, 2007a, 2007b). The most comprehensive results, which were published by WALSH \& WEPENER (2009), showed that $72 \%$ of the diatom taxa that were identified in streams with a significant agricultural impact were salt tolerant. The study was conducted in the Crocodile and Magalies Rivers in South Africa, where in some of the samples (conductivity over $600 \mu \mathrm{S} . \mathrm{cm}^{-1}$ ), the diatom index scores had a low to moderate integrity. Among the impacted sites, agricultural sites had a somewhat worse ecological status than urban sites according to the diatom indices. The reference sites were dominated by diatom species that preferred clean, freshwater and the indices that were calculated indicated a good ecological status, while the sites that had been impacted by an agricultural or urban influence had a poor to moderate status (WALSH \& WePener 2009). LaVoie et al. (2018) analysed the diatom assemblages from several streams and creeks of the Greater Sudbury River (Ontario, Canada). The results of these studies are another piece of evidence for the decrease in diatom biodiversity in water bodies that have been affected by an anthropogenic impact. The calculated Eastern Canadian Diatom Index (IDEC) had a 
better biological integrity at the reference sites (LAVOIE et al. 2018) that had had weak anthropogenic influences that was similar to our results. HusTEDT (1957) recorded that it is not the concentration of a particular salt in the water that influences freshwater diatoms the most but rather the osmotic pressure. Later experiments confirmed the fact that osmotic pressure is an important factor that limits the occurrence of sensitive freshwater diatom species (CLEAVE et al. 1981) by limiting their ability to absorb nutrients (TUCHMAN et al. 1984).

\section{Brackish and marine species in the analysed rivers}

Based on the cluster and the canonical correspondence analysis (CCA) analyses, we were able to indicate the differences between the diatom assemblages in the rivers with a strong and weak anthropogenic impact. The first populations were rich in taxa that preferred brackish or brackish-marine water and the second populations were dominated by taxa that preferred more fresh-brackish water. In the rivers with a strong anthropogenic salinisation, Pleurosira laevis was the dominant species. It is typically a halophilic, sometimes rheophilic species, known for its ability to live in freshwater environments (COMPÈRE 1982). In the beginning, P. laevis was recorded in freshwater, oligohaline environments of North America, e.g. the Colorado River in the Grand Canyon region (CRAYTON \& SOMMERFELD 1979), the Great Lakes (WUJEK \& WELLING 1981) or the Maumee River in Ohio (KocIOLEK et al. 1983). Later, the species was reported in Europe (Sims 1996; Gómez 2008; Perez et al. 2009), Asia (Joh 2010; KARTHICK \& KocioleK 2011; Sharifinia et al. 2016) and South America (Metzeltin \& GARCÍA-RodríGuez 2003). Recently, P. laevis was found in the Zarafshan River, which is one of the largest rivers in Uzbekistan (MAMANAZAROVAA \& GOLOLOBOVA 2017). Pleurosira laevis is mainly associated with brackish or marine environments where its populations grow along with an increase in the chloride levels of the water (WuJeK \& Welling 1981; KocioleK et al. 1983). In SHARIFINIA et al. (2016), this species occurred in sites that were characterised by conductivity that ranged from slightly over 600 to $1000 \mu \mathrm{S} \mathrm{cm}^{-1}$. In our study, P. laevis comprised $73 \%$ of all of the identified diatom taxa in the Bolina River and 21\% in the Mleczna River, although the values of their salinity (periodically exceeded 40000 and $7000 \mu \mathrm{S} . \mathrm{cm}^{-1}$, respectively) and noticeable concentration of sulfates (550 and almost $300 \mathrm{mg} . \mathrm{dm}^{-3}$, respectively). During a microscopic observation, we did not observe any significant teratologies of the $P$. laevis frustule, which usually suggests a response to ecological stress or metal pollution (LAVOIE et al. 2018). SCHRÖDER et al. (2015) analysed the benthic diatom assemblages of a Western Germany lowland river - the Lippe River. Its lower and middle courses had increased levels of salinity that were caused by coal mining activities (PETRUCK \& STÖFFLER 2011). The authors found that $31 \%$ of all of the diatom species were reliable salinity indicators and that five species were characterised by a positive relationship to increasing salinities: Amphora libyca Ehrenberg, Bacillaria paxillifera (O.F.Müller) T.Marsson, Navicula subhamulata Grunow in Van Heurck, Nitzschia inconspicua Grunow, Rhoicosphenia abbreviata (C.Agardh) Lange-Bertalot, of which Bacillaria paxillifera and Rhoicosphenia abbreviata also occurred in our studies. In the upper course of the Bolina River, Ctenophora pulchella constituted $63 \%$ of all of the identified taxa. This species primarily occurs in brackish waters in coastal regions but can also be found in freshwater bodies that have an increased conductivity, for example, in a polluted urban stream - Collins Channel, California, where the conductivity was almost $3000 \mu \mathrm{S} . \mathrm{cm}^{-1}$ (Jones 2013). Except for $P$. laevis and $C$. pulchella in the aforementioned rivers, we identified more diatoms that prefer brackish and marine environment such as Achnanthes brevipes var. intermedia (3\% of all of the taxa in the Bolina River), Halamphora coffeiformis ( $2 \%$ of the taxa in the Mleczna River), Halamphora luciae ( $2 \%$ of the taxa in the Bolina River), Navicula salinarum (1\% of the taxa in the Bolina River), Gyrosigma attenuatum (4\% of the taxa in the Bolina Rover) and Pleurosigma salinarum (1\% of the taxa in the Bolina River). In addition, Tabularia fasciculata (C.Agardh) D.M.Williams et Round comprised 6\% of all of the identified species in the entire Bolina River diatom population. It is a cosmopolitan species that has a worldwide distribution and a tolerance for wide ranges of salinity (SNOEIJS 1992). It has been found in marine, brackish as well as freshwater habitats (DAVIDOVICH et al. 2010). The relationship between benthic diatom assemblages and conductivity has been well studied in the USA where PotAPova \& CHARLES (2003) have analysed 3239 diatom samples from 1109 river sites located in different parts of North America, which have conductivity that ranges from 10 to almost $15000 \mu \mathrm{S} . \mathrm{m}^{-1}$. The authors considered a value of $1000 \mu \mathrm{S} . \mathrm{cm}^{-1}$ as the threshold between brackish and freshwater habitats. However, the results may have been underestimated in terms of the lack of a brackish water dataset, which caused species that prefer brackish waters to have their optima set below the aforementioned threshold (e.g. Ctenophora pulchella). Compared to our study, Pleurosira laevis, which dominated the downstream sites of the Bolina and Mleczna Rivers occurred in a conductivity of 44 $600 \mu \mathrm{S} . \mathrm{cm}^{-1}$ and $7090 \mu \mathrm{S} . \mathrm{cm}^{-1}$, respectively, during the inflow of polluted post-mining waters, while PoTAPOVA $\&$ CHARLES (2003) reported an optimum of $573 \mu{\mathrm{S} . \mathrm{cm}^{-1}}^{-1}$ with a maximum conductivity value of $1122 \mu \mathrm{S} . \mathrm{cm}^{-1}$ for the same species. Our results show that $P$. laevis is able to withstand periodic higher conductivity levels and grow (it was the dominant species in the Bolina River). A similar conclusion was drawn for other species, e.g. Ctenophora pulchella or Tabularia fasciculata. Determining the salinity preferences of individual species seems to be a very difficult task taking into account the multitude of water factors that affect individual diatom populations besides salinity. The occurrence of halophilous species is not always associated with an 
increased salinity. At the beginning of the $20^{\text {th }}$ century, Actinocyclus normanii (W.Gregory ex Greville) Hustedt, which was considered to be a marine species, appeared in rivers and at the end of that century, it occurred in many European inland water bodies (KIss et al. 1990; GEISSLER et al. 2006; KAŠTOVSKÝ et al. 2010). Later, a similar spread of Didymosphenia geminata (Lyngbye) Mart.Schmidt in A.Schmidt as well as Pleurosira laevis and Bacillaria paxillifera (FráNKovÁ-KozÁKová et al. 2007; HindaKoví et al. 2010) was observed in the Czech Republic (GÁGYOROVÁ \& MARVAN 2002). In terms of the periodic inflow of salinised mine waters into the Bolina and Mleczna Rivers, it is difficult to establish whether we observed a case of a marine species invasion or only examples of the short appearance of these organisms into unfavourable environmental conditions. There is a great need to carry out detailed studies on the diatom assemblages of saline rivers, especially on the ecological preferences of the dominant species in them.

\section{ACKNOWLEDGEMENTS}

The authors are grateful to LUKASZ PESZEK for his assistance with the SEM micrographs, Prof. ANDRZEJ WITKOwsKi for his helpful comments and to Michele L. Simmons, B.A. for improving the English style and to anonymous Reviewers and Editor (Aloisie Poulíčková) for providing constructive and valuable criticism on the original version of the manuscript. Funding for the diatom analysis originated from the Polish Ministry of Science and Higher Education's topical subsidy for the Palaeoceanology Unit, University of Szczecin.

\section{REFERENCES}

Ács, É.; Szabó, K.; TóTH, B. \& KIss, K.T. (2004): Investıgatıon of benthic algal communities, especially diatoms of some Hungarian streams in connection with reference conditions of the Water Framework Directives. - Acta Botanica Hungarica 46: 255-277. DOI: https://doi. org/10.1556/ABot.46.2004.3-4.1

BĄK, M. \& SZlauER-LuKaSZEWSKa, A. (2012): Bioindicative potential of diatoms and ostracods in the Odra mouth environment quality assessment. - Nova Hedwigia, Beiheft 141: 463-484.

BąK, M.; Witkowski, A.; LANGe-Bertalot, H. \& Dadal, A. (2004): Ecology of the Szczecin Lagoon diatom flora with reference to the utility of diatom indices in assessing water quality. - Japanese Journal of Diatomology 20: 23-31. DOI: https://doi.org/10.11464/diatom1985.20.0 23

BĄK, M.; WitKoWSKI, A.; ŻELAZNA-WieCZOREK, J.; WOJTAL, A.Z.; Szczepocka, E.; Szulc, K. \& SzulC, B. (2012): Key to the determination of diatoms in phytobenthos for the assessment of ecological status of water bodies in Poland. - 455 pp., Biblioteka Monitoringu Środowiska, Warszawa.

BAtTARBEe, R.W. (1986): Diatom analysis. - In: Berglund, B.E. (ed.): Handbook of Holocene Palaeoecology and Palaeohydrology. - pp. 527-570, Wiley \& Sons, Chichester.

Beauger, A.; Voldoire, O.; Mertens, A.; Le Cohu, R. \& VAN DE ViJver, B. (2015): Two new Navicula species (Bacillariophyceae) from Western Europe. - Phytotaxa 230: 172-182. DOI: http://dx.doi.org/10.11646/ phytotaxa.230.2.4

BoDÉN, P. (1991): Reproducibility in the random setting method for quantitative diatom analysis. - Micropalontology 37: 313-319. DOI: https://doi.org/10.2307/1485893

BUCKA, H. (1960): Phytoplankton of the experimental ponds in Gołysz. - Acta Hydrobiologica 2: 235-254.

Bucka, H. (1964): Some species of algae from ponds at Gołysz. - Acta Hydrobiologica 6: 317-321.

BuCKA, H. (1966): Plankton communities in the fish ponds of the Zespół Ochaby. - Acta Hydrobiologica 8: 13-46.

Cantonati, M.; Kelly, M.G. \& Lange-Bertalot, H. (2017): Freshwater benthic diatoms of Central Europe: over 800 common species used in ecological assessment. - 942 pp., Koeltz Botanical Books, Königstein.

Cantonati, M.; Saber, A.; Blanco, S.; El-Refaey, A.E.A.; SHEHATA, F.E. \& EL-GAMAL, D.A. (2016): Observations on some rarely-recorded Navicula species from Egyptian inland waters including the recently-described N. flandriae. - In: Pienitz, R. \& Zimmermann, C. (eds): Program \& Abstracts, 24 ${ }^{\text {th }}$ International Diatom Symposium, Québec, Canada, 21-26 August 2016. - pp. 271, Université Laval.

Čecháková, K., Matuszková, B.; Válová, E.; Truchlá, M.; ZaOralová, M.; Arnošová, L. \& STalmachová, B. (2014): A biological survey of selected groups of plants and animals in the flooded subsidence reservoirs in Upper Silesia. - In: GÂşTesCu, P.; MARszelewwski, W. \& Bretcan, P. (eds): Proceedings of $2^{\text {nd }}$ International Conference of Water resources and wetlands. Tulcea, Romania, 11-13 September 2014. - pp. 583, Romanian Limnogeographical Association.

Cholnoky, B.J. (1968): Die Oekologie der Diatomeen in Binnengewaessern. - 699 pp., J. Cramer, Lehre.

Cichoń, C. (2016): Craticula buderi (Bacillariophyceae) in Poland. - Polish Botanical Journal 61: 301-305. DOI: https://doi.org/10.1515/pbj-2016-0024

Clarke, K.R. \& WARwick, R. M. (2001): Change in marine communities: an approach to statistical analysis and interpretation, $2^{\text {nd }}$ edition. - 176 pp., Plymouth Marine Laboratory \& PRIMER-E Ltd, Plymouth.

Cleave, M.L.; Porcella, D.B. \& Adams, V.D. (1981): The application of batch bioassay techniques to the study of salinity toxicity to freshwater phytoplankton. - Water Research 15: 573-584. DOI: https://doi. org/10.1016/0043-1354(81)90020-8

Compère, P. (1982): Taxonomic revision of the diatom genus Pleurosira (Eupodiscaceae). - Bacillaria 5: 165-190.

Crayton, W.M. \& Sommerfeld, M.R. (1979): Composition and abundance of phytoplankton in tributaries of the lower Colorado River, Grand Canyon region. - Hydrobiologia 66: 81-93. DOI: https://doi.org/10.1007/BF00019143

Davidovich, N.A.; Kaczmarska, I. \& Ehrman, J.M. (2010): Heterothallic and homothallic sexual reproduction in Tabularia fasciculate (Bacillariophyta). - Fottea 10: 251-266. DOI: https://doi.org/10.5507/fot.2010.016

DenYs, L. (1991): A check-list of the diatoms in the holocene deposits of the Western Belgian coastal plain with a survey of their apparent ecological requirements. I. Introduction, ecological code and complete list. - 41 pp., Ministčre des Affaires Economiques, Service Géologique de Belgique.

ECTOR, L. \& Rimet, F. (2005): Using bioindicators to assess rivers in Europe: An overview. - In: LEK, S.; SCARDI M.; Verdonschot P.; Descy J.-P. \& PARK Y.S. (eds): Modelling Community Structure in Freshwater Ecosystems. - pp. 7-19, Springer Press, Berlin.

Fránková-Kozáková, M.; Marvan, P. \& Geriš, R. (2007): Halophilous diatoms in Czech running waters: Pleurosira 
laevis and Bacillaria paxillifer. - In: KUSBER W.-H. \& JAHN R. (eds): Proceedings of the $1^{\text {st }}$ Central European Diatom Meeting. Berlin, Germany, 23-25 March 2007. - pp. 39-44, Botanic Garden and Botanical Museum Berlin-Dahlem and Freie Universität Berlin. DOI: https://doi.org/10.3372/cediatom.108

GáGYorová, K. \& Marvan, P. (2002): Didymosphenia geminata and Gomphonema ventricosum (Bacillariophyceae) in Moravskosleyské Beskydy Mts. - Czech Phycology 2: $61-68$

GeIsSLER, U.; KuSBER, W.-H. \& JAHN, R. (2006): The diatom flora of Berlin (Germany): A spotlight on some documented taxa as a case study on historical biodiversity. - In: WitKowsKI A. (ed.): Proceedings of the Eighteenth International Diatom Symposium, Międzyzdroje, Poland, 2-7 September 2004. - pp. 91-105, International Society for Diatom Research.

GómEz, F. (2008): Phytoplankton invasions: comments on the validity of categorizing the non-indigenous dinoflagellates and diatoms in European Seas. - Marine Pollution Bulletin 56: 620-628. DOI: https://doi.org/10.1016/j. marpolbul.2007.12.014

HalabowsKi, D.; BielaŃSKa-GraJNER, I. \& LeWIN, I. (2019a): Effect of underground salty mine water on the rotifer communities in the Bolina River (Upper Silesia, Southern Poland) - Knowledge and Management of Aquatic Ecosystems 420: 31. DOI: https://doi.org/10.1051/ kmae/2019023"

Halabowski, D.; Krodkiewska, M.; Sowa, A. \& Lewin, I. (2019b): First record of the alien aquatic oligochaete species Monopylephorus limosus (Hatai, 1898) (Annelida) in Central Europe - Oceanological and Hydrobiological Studies 48: 290-295. DOI: https://doi.org/10.2478/ ohs-2019-0026

HANAK-SChMAGER, M. (1974): Seston and periphyton of the Vistula River along the section from Nowy Bierun till the stage of fall in Łączany as well as of the Channel Łączany-Skawina. - Acta Hydrobiologica 16: 345-365.

Hermanowicz, W.; DoJlido, J.; Dozanska, W.; Koziorowski, B. \& ZeRBE, J. (1999): Physical and chemical studies of water and wastewater. - 556 pp., Arkady, Warszawa.

Hindakova, A.; Houk, V.; JaneceK, E.; Kopp, R.; Marvan, P.; Pumann, P.; Skacelova, O. \& Zapomelov, E. (2010): A review of the alien and expansive species of freshwater cyanobacteria and algae in the Czech Republic. - Biological Invasions 12: 3599-3625. DOI: https:// doi.org/10.1007/s10530-010-9754-3

Hofmann, G.; Werum, M. \& Lange-Bertalot, H. (2011): Diatomeen im Süsswasser-Benthos von Mitteleuropa. - 908 pp., A.R.G. Gantner Verlag K.G., Koenigstein.

Hustedt, F. (1957): Die Diatomeenflora des Fluss-systems der Weser in Gebiet der Hansestadt Bremen. - Abhandlungen des Naturwissenschaaftlichen Vereins zu Bremen 34: $181-440$.

JoH, G. (2010): Algal flora of Korea. Freshwater diatoms I: Bacillariophyceae, Centrales. - 161 pp., National Institute of Biological Resources, Incheon.

JoNes, J. (2013): Ctenophora pulchella. - In: Diatoms of North America. Available from: https://diatoms.org/species/ ctenophora_pulchella. - accessed: 12 January 2019.

KARTHICK, B. \& KocioleK, J. (2011): Four new centric diatoms (Bacillariophyceae) from the Western Ghats, South India. - Phytotaxa 22: 25-40. DOI: http://dx.doi.org/10.11646/ phytotaxa.22.1.2

KaŠTovsKÝ, J.; HAUER, T.; MAREš, J.; KRAUTOVÁ, M.; BešTA, T.; KomÁreK, J.; Desortová, B.; HetešA, J.; Hindáková, A.;
Houk, V.; JaneČEK, E.; KopP, R.; Marvan, P.; Pumann, P.; SKácelová, O. \& ZapomĚLová, E. (2010): A review of the alien and expansive species of freshwater cyanobacteria and algae in the Czech Republic. - Biological Invasions 12: 3599-3625. DOI: https://doi.org/10.1007/ s10530-010-9754-3

Kelly, M.; King, L. \& Ní Chatháin, B. (2009): The conceptual basis of ecological-status assessments using diatoms. - Biology and Environment: Proceedings of the Royal Irish Academy 109B: 175-189.

KeLLY, M.G. (2002): Role of benthic diatoms in the implementation of the Urban Wastewater Treatment Directive in the River Wear, North-East England. - Journal of Applied Phycology 14: 9-18. DOI: https://doi. org/10.1023/A:1015236404305

Kiss, K.T.; Le Cohu, R.; Coste, M.; GenKal, S.I. \& HouK, V. (1990): Actinocyclus normanii (Bacillariophyceae), in some rivers and lakes in Europe. Morphological examinations and quantitative relations. - In: RICARD, M. (ed.): Ouvrage dédié à la mémoire du Professeur Henry Germain (1903-1989). - pp. 111-123, Koeltz Scientific Books, Koenigstein.

KocioleK, J.P.; Lamb, M.A. \& Lowe, R.L. (1983): Notes on the growth and ultrastructure of Biddulphia laevis Ehr. (Bacillariophyceae) in the Maumee River, Ohio, USA. - The Ohio Journal of Science 83: 125-130.

Krammer, K. \& LANGE-Bertalot, H. (1986): Bacillariophyceae. 1. Part: Naviculaceae. - In: Etll , H.; Gerloff, J.; Heynig, H. \& Mollenhauer, D. (eds): Süsswasserflora von Mitteleuropa. Vol. 2/1. - pp. 1-876, G. Fischer Verlag, Stuttgart, New York.

Krammer, K. \& Lange-Bertalot, H. (1988): Bacillariophyceae. 2. Part: Bacillariaceae, Epithemiaceae, Surirellaceae. - In: Etll , H.; GerlofF, J.; Heynig, H. \& Mollenhauer, D. (eds): Süsswasserflora von Mitteleuropa. Vol. 2/2. - pp. 1-596, G. Fischer Verlag, Jena.

Krammer, K. \& Lange-Bertalot, H., (1991a): Bacillariophyceae 3. Part: Centrales, Fragilariaceae Eunotiaceae. - In: Etll , H.; GerlofF, J.; Heynig, H. \& Mollenhauer, D. (eds): Süsswasserflora von Mitteleuropa. Vol. 2/3. pp. 1-576, G. Fischer Verlag, Stuttgart, Jena.

Krammer, K. \& LANGe-Bertalot, H. (1991b): Bacillariophyceae 4. Part. Achnanthaceae, Kritische Ergänzungen zu Navicula (Lineolatae) und Gomphonema. - In: ETLL , H.; Gerloff, J.; Heynig, H. \& Mollenhauer, D. (eds): Süsswasserflora von Mitteleuropa. Vol. 2/4. - pp. 1-437, G. Fischer Verlag, Stuttgart, Jena.

Krammer, K. (2000): The genus Pinnularia. - In: LangeBertalot, H. (ed.): Diatoms of the European inland waters and comparable habitats. Vol. 1. - pp. 1-703, A.R.G. Gantner Verlag K.G., Ruggell.

Krammer, K. (2002): Cymbella. - In: Lange-Bertalot H. (ed.): Diatoms of Europe, diatoms of the European inland waters and comparable habitats. Vol. 3. - pp. 1-584, A.R.G. Gantner Verlag K.G., Ruggell.

Krammer, K. (2003): Cymbopleura, Delicata, Navicymbula, Gomphocymbellopsis, Afrocymbula. - In: LANGEBerTaLOt, H. (ed.): Diatoms of Europe, Diatoms of the European Inland waters and comparable habitats. Vol. 4. - pp. 1-529, A.R.G. Gantner Verlag K.G., Ruggell.

KWANDRANS, J. (1998): The effect of dolomite on the sessile algae communities in an acidic mountain stream (Czarna Wisełka). - Studia Naturae 44: 125-143.

KWANDRANS, J. (2002): Upper Vistula River: Response of aquatic communities on pollution and impoundment. IX. Benthic diatom communities. - Polish Journal of 
Ecology 50: 223-236.

KwANDRANS, J. (2007): Diversity and ecology of benthic diatom communities in relation to acidity, acidification and recovery of lakes and rivers. -169 pp., A.R.G. Gantner Verlag K.G., Ruggell.

LANCE, G.N. \& Williams, W.T. (1967): A general theory of classificatory sorting strategies. I Hierarchical systems. - Computer Journal 9: 373-380.

Lange-Bertalot, H. \& Metzeltin, D. (1996): Indicators of oligotrophy -800 taxa representative of three ecologically distinct lake types, Carbonate buffered - Oligodystrophic - Weakly buffered soft water. - In: LANGE-BERTALOT, H. (ed.): Iconographia Diatomologica. Annotated Diatom Micrographs. Vol. 2: Ecology, Diversity, Taxonomy. - pp. 1-390, Koeltz Scientific Books, Königstein.

LANGe-Bertalot, H. (2001): Navicula sensu stricto. 10 Genera separated from Navicula sensu lato. Frustulia. - In: LANGE-BERTALOT, H. (ed.): Diatom of Europe, Diatoms of the European inland waters and comparable habitats. Vol. 2. - pp. 1-526, A.R.G. Gantner Verlag K.G., Ruggell.

LANGe-Bertalot, H.; BĄK, M. \& Witkowski, A. (2011): Eunotia and some related genera. - In: LANGE-BERTALOT, $\mathrm{H}$. (ed.): Diatoms of Europe, Diatoms of the European inland waters and comparable habitats. Vol. 6. - pp. 1-747, A.R.G. Gantner Verlag K.G., Ruggell.

Lavoie, I.; Morin, S.; Laderriere, V. \& Fortin, C. (2018): Freshwater Diatoms as indicators of Combined LongTerm Mining and Urban Stressors in Junction Creek (Ontario, Canada). - Environments 5: 30. DOI: https:// doi.org/10.3390/environments5020030

Levkov, Z. (2009): Amphora sensu lato. - In: LANGE-Bertalot, H. (ed.): Diatoms of Europe, Diatoms of the European inland waters and comparable habitats. Vol. 5. - pp. 5-916, A.R.G. Gantner Verlag K.G., Ruggell

Levkov, Z.; Metzeltin, D. \& Pavlov, A. (2013): Luticola and Luticolopsis. - In: LANGE-BERTALOT, H. (ed.): Diatoms of Europe, Diatoms of the European inland waters and comparable habitats. Vol. 7. - pp. 1-697, Koeltz Scientific Books, Koenigstein.

Levkov, Z.; Mitić-Kopanja, D. \& Reichardt, E. (2016): The diatom genus Gomphonema from the Republic of Macedonia. - In: LANGE-Bertalot, H. (ed.): Diatoms of Europe, Diatoms of the European inland waters and comparable habitats. Vol. 8. - pp. 1-552, Koeltz Botanical Books, Oberreifenberg.

LeWIN, I.; HALABOWSKI, D. \& RYMARSKI, Z. (2018): The first records of the occurrence of a North American invader Gammarus tigrinus Sexton, 1939 in the tributaries of the upper Vistula River. - Knowledge and Management of Aquatic Ecosystems 419: 31. DOI: https://doi. org $/ 10.1051 / \mathrm{kmae} / 2018021$

Lewin, I.; Spyra, A.; KrodkiewsKa M. \& StrZelec, M. (2015): The Importance of the Mining Subsidence Reservoirs Located Along the Trans-Regional Highway in the Conservation of the Biodiversity of Freshwater Molluscs in Industrial Areas (Upper Silesia, Poland). - Water Air Soil Pollut. 226: 189. DOI: https://doi.org/10.1007/ s11270-015-2445-Z

LI, L.; ZHENG, B. \& LIU, L. (2010): Biomonitoring and bioindicators used for river ecosystems: definitions, approaches and trends. - Procedia Environmental Science 2: 1510-1524. DOI: https://doi.org/10.1016/j.proenv.2010.10.164

MalinowsKa-Gniewosz, A.; CZerwiK-Marcinkowska, J.; Massalski, A.; Kubala-Kukuś, A.; MajewsKa, U. \& JANKOWSKI, M. (2018): Relationships between diatoms and environmental variables in industrial water biotopes of Trzuskawica S.A. (Poland). - Open Chemistry 16: 272-282. DOI: https://doi.org/10.1515/chem-2018-0033 MamanazarovaA, K.S. \& Gololobova, M. (2017): First record of diatom species Pleurosira laevis (Ehrenberg) Compère for Uzbekistan and Central Asia. - Russian Journal of Biological Invasions 8: 69-74. DOI: https:// doi.org/10.1134/S2075111717010088

Metzeltin, D. \& García-RodríGuez, F. (2003): Las diatomeas Uruguayas. - 210 pp., DIRAC Facultad de Ciencias, Universidad de la República, Uruguay.

Pan, Y.; Herlihy, A.; Kaufmann, P.; Wigington, J.; Van SiCKLE, J. \& Moser, T. (2004): Linkages among land-use, water quality, physical habitat conditions and lotic diatom assemblages: A multi-spatial scale assessment. - Hydrobiologia 515: 59-73. DOI: https:// doi.org/10.1023/B:HYDR.0000027318.11417.e7

Perez, M.C.; Maidana, N.I. \& Comas, A. (2009): Phytoplankton composition of the Ebro River estuary, Spain. - Acta Bot. Croat. 68: 11-27.

Petruck, A. \& Stöffler, U. (2011): On the history of chloride concentrations in the River Lippe (Germany) and the impact on the macroinvertebrates. - Limnologica 41:143-150. DOI: https://doi.org/10.1016/j.limno.2011.01.001

Picińska-FaŁtynowicz, J. \& BŁachuta, J. (2010): A Practical Guide: Sampling, Preparation and Processing of Diatom Phytobenthos Residing in Rivers and Lakes. - 79 pp., Instytut Meteorologii i Gospodarki Wodnej, Wrocław.

Picińska-Faltynowicz, J.; Blachuta, J.; Kotowicz, J.; MazUREK, M. \& Rawa, W. (2006): Select the types of water bodies river and lake to assess the ecological status based on phytobenthos with the recommendation of the methodology of collection and analysis of samples. -34 pp., Główny Inspektorat Ochrony Środowiska. Wrocław.

Piscart, C.; Moreteau, J-C. \& Beisel, J-N. (2005): Biodiversity and structure of macroinvertebrate communities along a small permanent salinity gradient (Meurthe River, France). - Hydrobiologia 551: 227-236. DOI: https:// doi.org/10.1007/s10750-005-4463-0

PN-EN 13946 (2014): Water quality - Guidelines for routine sampling and preliminary preparation for the analysis of benthic diatoms from rivers and lakes. -19 pp., Polski Komitet Normalizacyjny, Warszawa.

PN-EN 14407 (2014): Water quality - Guidelines for the identification and enumeration of benthic diatom samples from rivers and lakes. - 15 pp., Polski Komitet Normalizacyjny, Warszawa.

Poikane, S.; Kelly, M. \& Cantonati, M. (2016): Benthic algal assessment of ecological status in European lakes and rivers: Challenges and opportunities. - Sci. Total Environ. 568: 603-613. DOI: https://doi.org/10.1016/j. scitotenv.2016.02.027

Potapova, M. \& Charles, D.F. (2003): Distribution of benthic diatoms in U.S. rivers in relation to conductivity and ionic composition. - Freshwater Biol. 48: 1311-1328. DOI: https://doi.org/10.1046/j.1365-2427.2003.01080.x

SatBaltyk (2018): Satellite Monitoring of the Baltic Sea Environment. Institute of Oceanology PAN. - Available from: http://www.satbaltyk.pl/ (accessed: 1 June 2018).

SChröDer, M.; Sondermann, M.; Sures, B. \& Hering, D. (2015): Effects of salinity gradients on benthic invertebrate and diatom communities in a German lowland river. - Ecological Indicators 57: 236-248. DOI: https:// doi.org/10.1016/j.ecolind.2015.04.038

SHANNON, C.E. (1948): A Mathematical Theory of Communication. - Bell System Technical Journal 27: 623-666. DOI: https://doi.org/10.1002/j.1538-7305.1948.tb01338.x 
Sharifinia, M.; RAMEZANPOUR, Z. \& NAMIN, J.I. (2016): Distribution of benthic centric diatom Pleurosira laevis (Compère, 1982) in different substrate type and physical and chemical variables. - Acta Limnologica Brasiliensia 28: e18. DOI: http://dx.doi.org/10.1590/ S2179-975X2416

Sims, P.A. (1996): An atlas of British diatoms arranged by B. Hartley based on illustrations by H.G. Barber and J.R. Carter. - 601 pp., Biopress Ltd., Bristol.

Snoeiss, P. (1992): Studies in the Tabularia fasciculate complex. - Diatom Research 7: 313-344. DOI: https://doi.org/1 0.1080/0269249X.1992.9705223

SolaK, C.N.; Barinova, S.; Ács, É. \& DayıoĞlu, H. (2012): Diversity and ecology of diatoms from Felent creek (Sakarya river basin), Turkey. - Turkish Journal of Botany 36: 191-203. DOI: https://doi.org/10.3906/bot-1102-16

Sowa, A.; KrodkiewsKa, M. \& Halabowski, D. (2018): Macroinvertebrate communities on various microhabitats of a saline coal mine settling pond. - Oceanological and Hydrobiological Studies 47: 50-59. DOI: https://doi. org/10.1515/ohs-2018-0006

Spyra, A.; KubickA, J. \& STRZelec, M. (2015): The influence of the disturbed continuity of the river and the invasive species Potamopyrgus antipodarum (Gray, 1843), Gammarus tigrinus (Sexton, 1939) on benthos fauna: a case study on urban area in the River Ruda (Poland). - Journal of Environmental Management 56: 233-244. DOI: https://doi.org/10.1007/s00267-015-0483-3

StaRmach, K. (1939): Research of seston in the upper Vistula and Biała Przemsza. - Sprawozdanie Komisji Fizjograficznej PAU 73: 1-145.

Ter BraAk, C.J.F. \& Šmilauer P. (2002): CANOCO Reference manual and CanoDraw for Windows User's Guide: Software for Canonical Community Ordination (version 4.5), 2nd ed. - Microcomputer Power, Ithaca, New York.

TAYLOR, J.C.; HaRding, W.R.; ARChIBALD, G.C.M. \& VAN RENSBURG, L. (2005): Diatoms as indicators of water quality in the Jukskei-Crocodile River system in 1956 and 1957, a re-analysis of diatom count data generated by B.J. Cholnoky. - Water SA 31: 1-10. DOI: http:// dx.doi.org/10.4314/wsa.v31i2.5176

Taylor, J.C.; Janse Van Vuuren, M.C. \& Pieterse, A.J.H. (2007a): The application and testing of diatom-based indices in the Vaal and Wilge Rivers, South Africa. Water SA 33: 51-59. DOI: http://dx.doi.org/10.4314/ wsa.v33i1.47871

Taylor, J.C.; Prygiel, J.; Vosloo, A.; De La Rey, P.A. \& Van RENSBERG, L. (2007b): Can diatom-based pollution indices be used for biomonitoring in South Africa? A case study of the Crocodile West and Marico water management area. - Hydrobiologia 592: 455-464. DOI: https://doi.org/10.1007/s10750-007-0788-1

Trojan, P. (1975): Ekologia ogólna. - 419 pp., Wydawnictwo Naukowe PWN, Warszawa.

Tuchman, M.L.; Theriot, E. \& StOERmer, E.F. (1984): Effects of low level salinity concentrations on the growth of Cyclotella meneghiniana. - Archiv fur Protistenkunde 128: 319-326. DOI: https://doi.org/10.1016/S0003-9365(84)80003-2

TÜMPLING, W.V. \& FrIEDRICH, G. (1999): Methoden der Biologischen Wasseruntersuchung, Bd. 2. - Biologische Gewässeruntersuchung. - 545 pp., Gustav Fisher Verlag, Stuttgart.

Van Dam, H., Mertens, A. \& Sinkeldam, J.A. (1994): A coded check list and ecological indicator values of freshwater diatoms from the Netherlands. - Aquatic Ecology 28: 117-133. DOI: https://doi.org/10.1007/BF02334251
Vilbaste, S.; JärvekÜlg, R.; Pall, P.; PiIrsoo, K.; Trei, T. \& VIIK, M. (2004): Diatom indices and stream typology in Estonia. - Oceanological and Hydrobiological Studies 33: 3-10.

WALsh, G. \& WePENER, V. (2009): The influence of land use on water quality and diatom community structures in urban and agriculturally stressed rivers. - Water SA 35: 5. DOI: http://dx.doi.org/10.4314/wsa.v35i5.49184

WFD (2000): EU Water Framework Directive 2000/60/EC. European Commission. - Available from: http://ec.europa. eu/environment/water/water-framework/index_en.html (accessed: 29 September 2018).

WilK-Woźniak, E.; Pociecha, A.; Ciszewski, D.; AleksanderKwaterczaK, U. \& WalusiaK, E. (2011): Phyto- and zooplankton in fishponds contaminated with heavy metal runoff from a lead-zinc mine. - Oceanological and Hydrobiological Studies 40: 77-85. DOI: https:// doi.org/10.2478/s13545-011-0044-1

WiLliams, W.D. (1987): Salinisation of rivers and streams: an important environmental hazard. - Ambio 16: 180-185.

Witkowski, A.; LANGe-Bertalot, H. \& Metzeltin, D. (2000): Diatom Flora of Marine Coasts I. - Iconographia Diatomologica 7: 1-925.

WoJtal, A.Z. \& KWANDRANS, J. (2006): Diatoms of the Wyżyna Krakowsko-Częstochowska upland (S Poland) Coscinodiscophyceae (Thalassiosirophycidae). - Polish Botanical Journal 51: 177-207.

Wojtal, A.Z. (2013): Species composition and distribution of diatom assemblages in spring waters from various geological formations in southern Poland. - Bibliotheca Diatomologica 59: 1-436.

WuJEK, D.E. \& Welling, M.L. (1981): The occurrence of 2 centric diatoms new to the Great Lakes, USA. - Journal of Great Lakes Research 7: 55-56. DOI: http://dx.doi. org/10.1016/S0380-1330(81)72024-0

Zgrundo, A.; Peszek, L. \& Poradowska, A. (2018): Manual for monitoring and evaluation of river surface water bodies based on phytobenthos. - 70 pp., Główny Inspektorat Ochrony Środowiska, Gdańsk.

Supplementary material

The following supplementary material is available for this article:

Supplementary plates.

This material is available as part of the online article (http:// fottea.czechphycology.cz/contents)

(C) Czech Phycological Society (2020)

Received January 1, 2019

Accepted August 29, 2019 